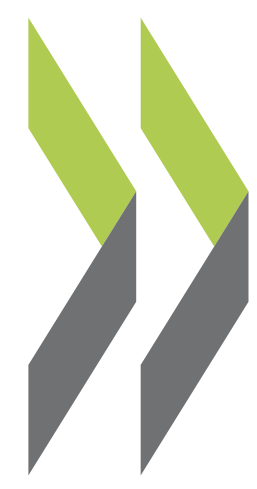

OECD Regional Development Working Papers 2014/05

What Makes Cities More Productive? Evidence on the Role of Urban Governance from Five OECD Countries

\author{
Rudiger Ahrend, \\ Emily Farchy,
}

loannis Kaplanis,

Alexander C. Lembcke 


\section{OECD REGIONAL DEVELOPMENT WORKING PAPERS}

This series is designed to make available to a wider readership selected studies on regional development issues prepared for use within the OECD. Authorship is usually collective, but principal authors are named. The papers are generally available only in their original language English or French with a summary in the other if available.

OECD Working Papers should not be reported as representing the official views of the OECD or of its member countries. The opinions expressed and arguments employed are those of the author(s).

This document has been produced with the financial assistance of the European Union. The views expressed herein can in no way be taken to reflect the official opinion of the European Union.

Working Papers describe preliminary results or research in progress by the author(s) and are published to stimulate discussion on a broad range of issues on which the OECD works. Comments on Working Papers are welcomed, and may be sent to either gov.contact@oecd.org or the Public Governance and Territorial Development Directorate, OECD, 2 rue André-Pascal, 75775 Paris Cedex 16, France.

Authorised for publication by Rolf Alter, Director, Public Governance and Territorial Development Directorate, OECD.

OECD Regional Development Working Papers are published on http://www.oecd.org/gov/regional/workingpapers

Applications for permission to reproduce or translate all or part of this material should be made to: OECD Publishing, rights@oecd.org or by fax 33145249930.

(C) OECD 2014 


\title{
WHAT MAKES CITIES MORE PRODUCTIVE? EVIDENCE ON THE ROLE OF URBAN GOVERNANCE FROM FIVE OECD COUNTRIES
}

\author{
Rudiger Ahrend, Emily Farchy, Ioannis Kaplanis, Alexander C. Lembcke $e^{1,2}$
}

\begin{abstract}
:
This paper estimates agglomeration benefits based on city productivity differentials across five OECD countries (Germany, Mexico, Spain, United Kingdom, and United States). It highlights the relationship between cities' governmental fragmentation and productivity, and represents the first empirical analysis of how metropolitan governance structures affect this relationship. The comparability of results in a multicountry setting is supported through the use of Functional Urban Areas - an internationally harmonised definition of cities based on economic linkages rather than administrative boundaries. In line with the previous literature, the analysis confirms that city productivity tends to increase with city size; doubling city size is found to be associated with an increase in productivity of between two and five percent. What is more, city productivity is positively associated with the population size of nearby cities. On the governance side, the paper finds that cities with fragmented governance structures tend to have lower levels of productivity. For a given population size, a metropolitan area with twice the number of municipalities is associated with around six percent lower productivity; an effect that is mitigated by almost half by the existence of a governance body at the metropolitan level.
\end{abstract}

JEL classification codes: R12; R23; R50; H73

Keywords: Cities; productivity; governance; agglomeration economies.

1. OECD Working Papers should not be reported as representing the official views of the OECD or of its member countries. The opinions expressed and arguments employed are those of the authors. Working Papers describe preliminary results or research in progress by the authors and are published to stimulate discussion on a broad range of issues on which the OECD works. Comments on Working Papers are welcomed, and may be sent to the Directorate of Public Governance and Territorial Development, OECD, 2 rue André-Pascal, 75775 Paris Cedex 16, France. Corresponding author: Ioannis.Kaplanis@ oecd.org.

2. The authors are indebted to Luis Diaz, Andreas Georgiadis, Claudia Tello, and Dimitris Mavridis for collaboration on the country specific studies and useful discussions at various stages of the research. This research has benefited from comments from Lewis Dijkstra, Soo-Jin Kim, Joaquim Oliveira Martins, Abel Schumann, William Tompson, and other members of the Regional Development Policy Division of the OECD, as well as from session participants at an ERSA Workshop (University of Barcelona, 2013) and an OECD Regional Development Seminar. We would also like to thank Richard Welpton from the UK Data Service for help with the used UK datasets and the staff of the Research Data Centre (FDZ) of the German Federal Employment Agency at the Institute for Employment Research for their help in accessing and remotely processing the German data. 


\section{Résumé :}

Ce papier présente une estimation des bénéfices d'agglomération sur la base des différences de productivité des villes à travers cinq pays de l'OCDE (Allemagne, Mexique, Espagne, Royaume-Uni et Etats-Unis). Il souligne la relation entre la fragmentation administrative des villes et la productivité de celles-ci, et représente la première analyse empirique de la manière dont les structures de gouvernance métropolitaine affectent cette relation. Les résultats des différents pays sont rendus comparables grâce à l'utilisation des zones urbaines fonctionnelles - une définition des villes harmonisée au niveau international et fondée sur les liens économiques plutôt que sur les frontières administratives. En ligne avec la littérature antérieure, l'analyse confirme que la productivité des villes augmente avec la taille de cellesci ; un doublement de la taille des villes est associé à une hausse de productivité de l'ordre de $2 \%$ à $3 \%$. En outre, la productivité des villes est associée de manière positive à la taille de la population dans les villes avoisinantes. En matière de gouvernance, le papier conclut que les villes dotées de structures fragmentées de gouvernance ont tendance à connaître des niveaux plus faibles de productivité. Pour une même taille de population, une zone métropolitaine qui comporte deux fois plus de municipalités est associée à une productivité plus faible d'environ 6\%; un effet qui est atténué de presque moitié par l'existence d'une structure de gouvernance au niveau métropolitain.

Codes JEL : R12; R23; R50; H73

Mots clefs : villes; productivité; gouvernance; bénéfices d'agglomération. 
TABLE OF CONTENTS

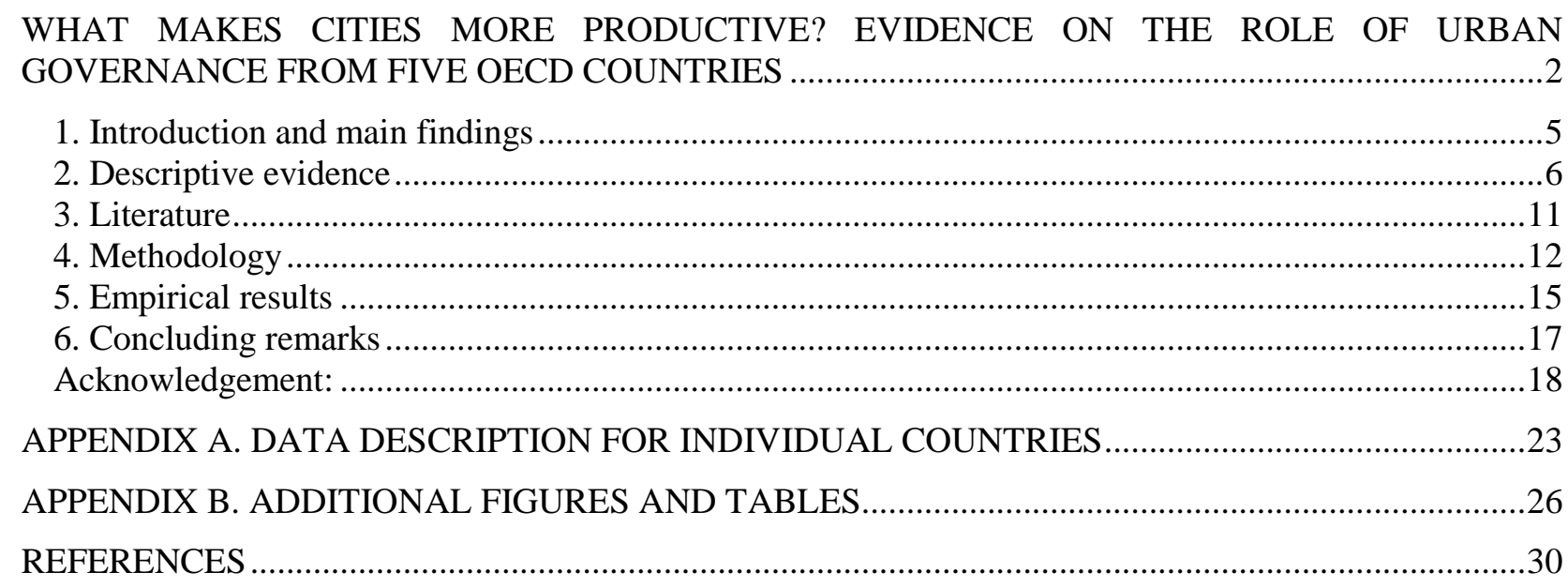

\section{Tables}

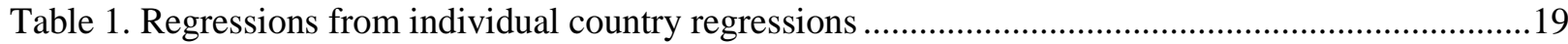

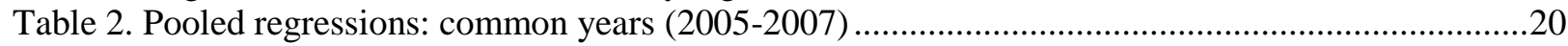

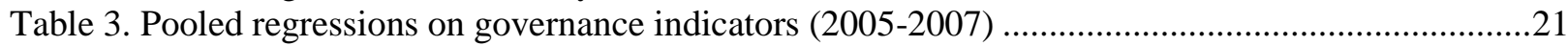

Table 4. Robustness checks with alternative fragmentation indicators $(2005-2007)$...............................22

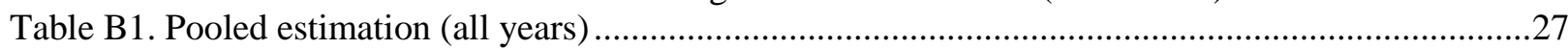

Table B2. Pooled estimation for metropolitan areas only (2005-2007) …........................................28

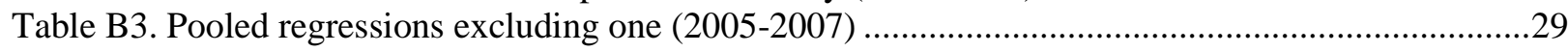

\section{Figures}

Figure 1. Population size and productivity by city (2007) ...............................................................

Figure 2. Administrative fragmentation and productivity by city....................................................10

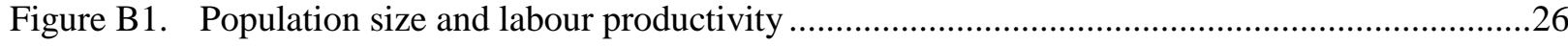




\section{Introduction and main findings}

A country's productivity is, in large part, determined by the productivity of its cities. Metropolitan areas - urban agglomerations with more than half a million inhabitants - are home to over half of the population of OECD member countries and account for an even larger share of total GDP. Given the need to raise the potential for long term growth, understanding how to increase the productivity of these cities is therefore an urgent policy question.

It is well known that, in many countries, the economic productivity of a city increases with its size. This is in part a result of sorting, as better educated individuals have a tendency to live and work in larger cities. However, even beyond this compositional effect, in recent years a substantial body of evidence has accumulated that suggests the productivity of a given individual increases with the size of the city in which they work.

In addition to identifying the existence of such agglomeration externalities, the literature has begun to make progress towards identifying their determinants. However, where existing research has been confined to single country studies, this paper combines evidence on agglomeration benefits in cities from five OECD member countries (Germany, Mexico, Spain, United Kingdom, and United States). This is done in a coherent and comparable econometric framework that - building upon a new harmonised definition of Functional Urban Area (FUA) jointly developed by the EU and the OECD - accounts for selection of more productive individuals into urban agglomerations.

In a first step, the paper uses micro-data on wages to estimate city productivity premiums, as captured by wage-premiums, for each of the cities within the five OECD countries under study. In a second step, the paper explores the determinants of these estimated city productivity premiums, for example looking at measures of human capital, industrial spill-overs or urban governance structures.

The novelties of this paper are twofold; in the first place, using data on Functional Urban Areas as defined by the OECD Metropolitan Areas Database, the paper is able to conduct a multi-country investigation into the magnitude and causes of agglomeration benefits that is not biased by differentially defined national administrative boundaries of cities. In the second place, using these FUAs, the paper is able to contrast the complexity of administrative boundaries by functional urban area, and hence examine the role of urban governance structures in determining the economic productivity of a city. ${ }^{3}$

The main findings are the following:

- Productivity tends to increase with city size for each of the five countries considered. ${ }^{4}$ When the five samples are combined, robust evidence for these agglomeration benefits is found with an estimated elasticity in the range of 0.02-0.05, implying that doubling a FUA's population is associated with roughly a $2-5 \%$ increase in productivity. This implies, e.g., that labour productivity in urban agglomerations of the size of Paris, London or Chicago would - on average - be in the order of $20 \%$ higher than in an urban agglomeration of 50,000 inhabitants. ${ }^{5}$ For a

3. Better urban governance structures have been shown to be associated with more efficient transport systems and land use (Ahrend, Gamper and Schumann, 2014), and may hence be expected to affect economic productivity.

4. Throughout the paper "city" will be used synonymously with "Functional Urban Area". When specific reference to the core city of a FUA is made, this is indicated in the text.

5. Using an elasticity of 0.04 . For an elasticity of 0.02 this figure would be roughly $10 \%$, for 0.05 roughly $27 \%$. 
given city size, city productivity premiums can vary substantially within a country, pointing to the existence of determinants other than city size or population density.

- Within countries, cities with fragmented governance structures have lower levels of productivity. For a given population size, a metropolitan area with twice the number of municipalities is associated with around 6\% lower productivity, an effect that is mitigated by almost half when a governance body at the metropolitan level exists.

- Human capital appears to play a strong direct role in influencing individual productivity as well as an indirect role through human capital externalities. Human capital externalities are evidenced when the productivity of an individual with a given level of education is dependent upon the general education level in the city in which they live. The analysis of this paper finds that a ten percentage point increase in the share of university graduates in a city is associated with an increase in productivity of approximately 3 percent through human capital externalities. It should be emphasized that this human capital externality accrues in addition to the (even larger) direct effect of human capital in enhancing individual productivity.

- No systematic evidence is found that, in the countries studied in this paper, city productivity premiums in capital cities are of a different magnitude to those in other cities of a comparable size. In contrast, port cities are found to have about three percent higher productivity levels.

- The results also provide evidence that proximity to nearby populous cities affects positively the productivity of a city, implying that - in a certain sense - cities can take advantage of the agglomeration of their neighbours. If, discounted by distance, the size of the population living in FUAs within a $300 \mathrm{~km}$ radius is twice as high, the productivity of the central FUA is between 1 and 2 percent higher.

- Specialization in certain types of activities appears to affect productivity levels. Cities with a higher share of manufacturing, finance and business services are found to have higher levels of productivity.

- When disaggregating manufacturing into high- and low-tech, this paper finds evidence that cities with a higher share of high-tech activities have larger city productivity premiums. This finding is consistent with the notion that individuals working in enterprises with high levels of knowledge based capital are more productive.

Section 2 presents descriptive evidence, Section 3 reviews briefly the related literature, Section 4 discusses the methodology, and Section 5 presents the estimation results.

\section{Descriptive evidence}

There is substantial evidence that metropolitan workers are more productive, but there remains a substantial degree of heterogeneity across estimates and across countries (Melo, Graham and Noland, 2009). The earlier literature, ignoring selection effects, showed that "[i]n sum, doubling city size seems to increase productivity by an amount that ranges from roughly 3-8\%" (Rosenthal and Strange, 2004, p. 2133). More recent work, which takes into account that more productive individuals tend to live in larger cities, finds agglomeration benefits in the order of 2-5\% (Combes, Duranton and Gobillon, 2011). The results of this paper are in line with the latter findings.

Figure 1 presents the level of city productivity premiums on the vertical axis and plots these against the size of the city - as measured by population. Panel A combines the five countries studied in this paper 
while Panels B to F are disaggregated by country. For all countries studied in this paper productivity is higher in larger cities; an upward trend is identified in each of the country cases, though of varying steepness. The countries differ also in the extent to which productivity varies across cities of similar size, with city productivity in the United Kingdom, the United States and Germany being far more homogenous than the productivity across cities in Spain and Mexico.

In the case of the United Kingdom it is interesting, but perhaps unsurprising, to note that city productivity premiums in London are larger even than those that would be expected given its size. Furthermore, alongside human capital, proximity to London appears to account for much of the performance of the positive outliers. Bracknell, Wokingham, Basingstoke, High Wycombe and Guilford all with high levels of tertiary education - are all within a 50km radius from London (with the exception of Basingstoke, which is located $77 \mathrm{~km}$ away). In contrast, there is no specific geographical pattern among the negative outliers though all have education levels below the United Kingdom's average. ${ }^{6}$

In Spain, city productivity premiums in Madrid are slightly below what would be expected for a FUA of its size, a result that is, in part, driven by particularly strong city productivity premiums in a number of mid-sized cities. In Germany, the most noteworthy feature is probably the strong east-west divide, with city productivity premiums in East German cities being, on the whole, significantly below the levels found in West German cities of comparable size. In line with this finding, the city productivity premium in Berlin lies in between the trends in East and West Germany. It is also noteworthy that a number of mid-sized German cities have city productivity premiums at levels similar to Munich, Stuttgart and Frankfurt - the most productive large agglomerations. This probably reflects a number of highly productive SME clusters in the manufacturing sector that - often for historical reasons - are located in smaller agglomerations.

In Mexico, there is a clear north-south divide. Negative outliers are mostly agglomerations in the south of the country, whereas positive outliers are generally located in the north, on or close to the US border. In contrast, some of the negative outliers in the United States are located on or close to the Mexican border. Also, other underperforming cities (including Chicago and Los Angeles) are relatively sprawled cities with low employment densities and relatively fragmented labour markets. ${ }^{7}$

6. Walsall and Hastings are the two largest negative outliers. The former is an industrial town in West Midlands with particularly low levels of tertiary education at $12 \%$, and the latter a South East town with similarly low education levels at 15\%, while the average for the United Kingdom was 20\% in 2007.

7. In the case of Chicago a relatively fragmented labour market due to deficiencies in the public transport system might contribute to its underperformance (c.f. OECD, 2012b). 
Figure 1. Population size and productivity by city (2007)

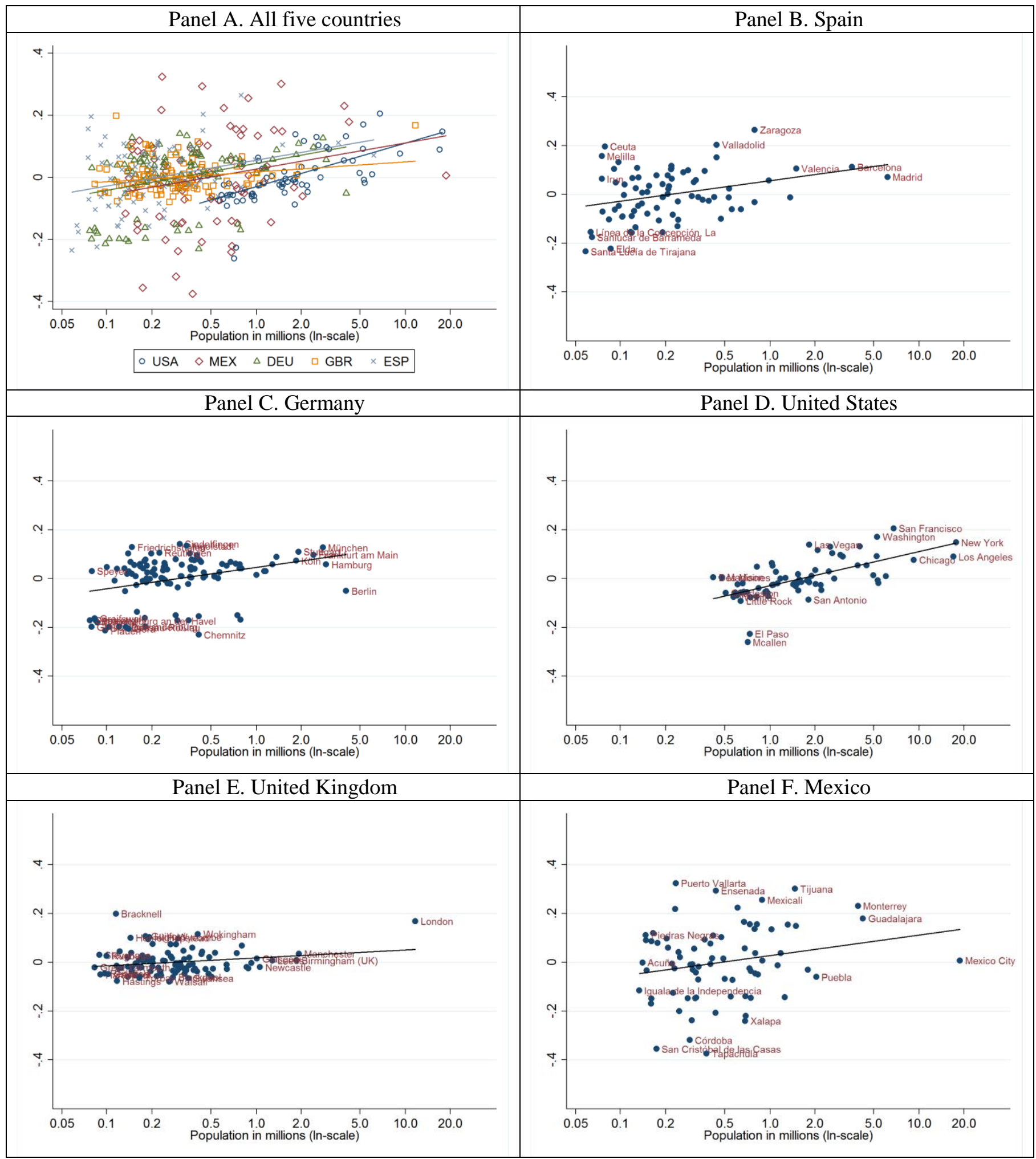

Note 1: With the natural logarithm of population on the horizontal axis, the vertical axis plots city productivity, estimated by applying individual wage regressions to national micro-data in order to control for workforce composition of cities. Log hourly wages/earnings are regressed on gender, experience, education, occupation and city-year dummies; the coefficients of the latter are taken to denote productivity differentials. The analysis is conducted at the Functional Urban Area level.

Source: Own calculations based on micro-data from national surveys. 
The descriptive country charts in Figure 2 illustrate the degree to which administrative fragmentation is associated with city productivity premiums. The degree of fragmentation of urban areas is measured by the number of municipalities per 100,000 inhabitants. ${ }^{8}$ The charts show a tendency for more fragmented cities to have lower levels of economic productivity. The effect varies across countries and is largest in Mexico (Panel F).

For some time, the urban planning literature has highlighted the role of co-operation and coordination among horizontal governance structures as a substitute for administrative consolidation in enhancing urban productivity (e.g. Blair, Staley and Zhang, 1996). This substitutability may shed some light on the strength of the impact of fragmentation in Mexico. Mayors of Mexican cities are elected for a three year term and are prohibited from running for immediate re-election. Furthermore, a large share of civil servants is replaced after each election cycle. This discontinuity in personnel may render it difficult to establish lasting co-operation across municipalities, potentially multiplying effects of fragmentation. In contrast, in the other countries, many cities have reasonably well-functioning coordination bodies, which - to some degree - may mitigate problems of fragmentation.

8. Municipalities for Germany, Mexico, Spain; local authority districts for the United Kingdom, and counties for the United States. 
Figure 2. Administrative fragmentation and productivity by city

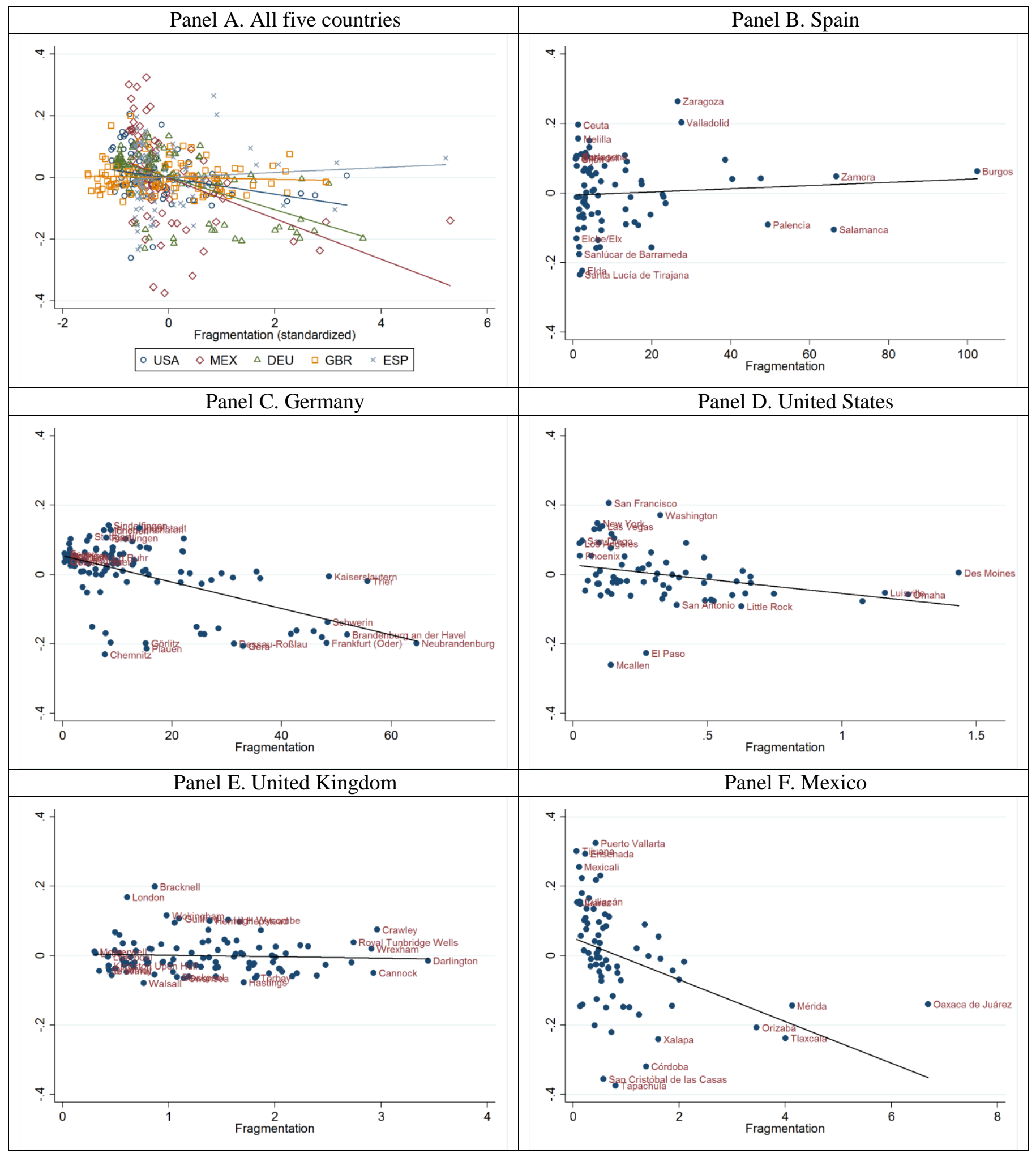

See note of Figure 1. Fragmentation is the number of municipalities per 100,000 inhabitants. 


\section{Literature}

The large theoretical literature on agglomeration economies/externalities (see the reviews of Rosenthal and Strange, 2004; Duranton and Puga, 2004; and Puga, 2010) tends to conclude that agglomeration benefits accrue through learning, through knowledge sharing, through specialization, and through deep labour markets. In examining the determinants of agglomeration benefits, this paper aims at disentangling some of these mechanisms.

If agglomeration externalities accrue through learning and knowledge sharing it is intuitive that, at the aggregate level, the magnitude of agglomeration externalities would differ with skill level of the city. Recent work finds evidence of complementarity between skills and density in determining the magnitude of the agglomeration productivity premium. Glaeser and Resseger (2010) find agglomeration benefits to be present only in relatively skilled cities. And, in line with a standard supply and demand framework, Moretti (2004) shows empirically that more skilled cities increase the productivity of unskilled workers.

It is also intuitive - given the importance of sharing and specialization - that, to some extent, agglomeration externalities are industry specific. And it is hardly surprising that the spatial distribution of economic activity is characterised by industrial clustering - firms specializing in related industries tend to cluster together in the same urban area. Using the reported location rankings of profit-maximizing firms to identify a counterfactual to a new plant opening, Greenstone, Hornbeck and Moretti (2010) identify a significant impact on the productivity of incumbent firms as a result of the localised entry of a new manufacturing establishment. The estimated productivity spillover appears to increase with various measures of economic proximity between the new plant and the incumbent plant.

While not directly covered in the existing literature on the productivity benefits of agglomeration, the influence of governance structures on urban outcomes is generally thought to be pervasive (World Bank, 2009; UN, 2013). Governance failures in agglomerations often result from the fact that administrative boundaries rarely coincide with the extent of economic activity. Problems arise in particular in areas that require not only coordination across different levels of government, but also horizontal coordination across numerous local governments at the same level.

Fragmentation in Functional Urban Areas varies strongly between countries, but FUAs frequently combine several hundred municipalities (OECD, 2013). This adds a high degree of complexity to coordination and may therefore stymie the extent to which agglomeration enhances productivity. In particular, administrative fragmentation can obstruct transport infrastructure investments and effective land use planning, thereby increasing congestion and reducing a city's attractiveness for individuals and businesses (see Ahrend, Gamper and Schumann, 2014; Kim, Schumann and Ahrend, 2014). Fragmentation may also pose problems in the area of business and environmental regulation, for example as the additional bureaucracy associated with fragmented governance could impede growth through its effect on the ease of doing business (see Djankov, McLiesh and Ramalho, 2006, on the impact of business regulation on growth).

Cheshire and Gordon (1996) hypothesise that a mismatch between administrative and functionallydefined city boundaries can result in failures to implement "growth promoting policies" as spillovers from these policies are not fully internalized by the managing (and funding) administrative bodies. In addition, where a functional region is represented by a smaller number of public agencies, transaction costs associated with growth promotion policies are likely to be lower. The result, they posit, is that the proportion of the functional regions' population located in the central administrative jurisdiction would be associated with more growth promoting policies and thereby growth, providing some econometric evidence for this hypothesis. 
In a similar vein, Cheshire and Magrini (2009) follow an empirical investigation that focuses on population ratios and concentrate attention on the salience of the economic interests of the central administrative jurisdiction of the functional region. In contrast, the analysis of this paper focusses on governmental fragmentation, and the administrative complexity and coordination difficulties that accompany it, as well as on the potential role of governance bodies in overcoming this fragmentation.

\section{Methodology}

Urban productivity arises, in part, from a tendency of more talented individuals to co-locate in cities. This may occur either because the initial distribution of workers' skills differs by city size, or because workers may sort by skills (Berry and Glaeser, 2005; Baum-Snow and Pavan, 2012). A large body of empirical work finds evidence that skill levels increase with city size (e.g. Combes, Duranton and Gobillon, 2008; Gibbons, Overman and Pelkonen, 2010). These studies also show that a sizeable share of the urban wage premium can be explained by observable and unobservable worker characteristics. It is therefore critical to account for this individual sorting of highly skilled individuals into cities when estimating productivity differentials across Functional Urban Areas (Combes, Duranton and Gobillon, 2011). Ignoring this selection will lead to confounding agglomeration benefits with productivity increases from a more skilled workforce.

Empirical work attempting to quantify the productivity premium, while accounting for selective sorting, has followed two paths. The first is based on the equilibrium location decisions of firms - under the assumption that firms will locate where they are most productive (see e.g. Ellison and Glaeser, 1997; Rosenthal and Strange, 2003). The second strand of empirical work, and the one pursued in this paper, focusses instead on the productivity of workers. Empirical work along these lines has found a relation between urban density and productivity - as proxied by wages - that continues to hold after controlling both for observable and (permanent) unobservable individual characteristics (e.g. Glaeser and Maré, 2001). ${ }^{9}$

The main contribution of this paper in terms of its methodological approach is the common empirical strategy applied across five OECD countries. This not only ensures that the individual country results are comparable, but allows for pooled regressions on the full sample of cities from five countries. This harmonised approach is made possible through the use of a definition of "city" that is based on economic linkages, rather than administrative boundaries, and is therefore comparable across countries.

Administrative and functional definitions of cities do not always coincide. Many who work in central London, for example, commute to work from its surrounding municipalities. Likewise, manufacturing sites that are located on the outskirts of a city could require their workers to commute out. According to an administrative definition such commuting workers would not live and work in the same urban area, whereas a functional definition would avoid this bias. More generally, a sole focus on the central administrative unit of a city will underestimate the population size of an urban area, overestimate the density, and might over- or underestimate its productivity. The empirical analysis of this paper therefore employs the Functional Urban Area (FUA) definition of cities.

"Functional Urban Area" is a new city definition proposed by OECD and EU that is based on urban economic functions rather than administrative boundaries. It has been applied in a comparable way across most OECD countries, aggregating contiguous lower spatial units that form part of a common Functional

9. Much of the literature uses wages as a proxy for productivity. Under standard wage setting mechanisms, the marginal product of labour should be reflected in wages. Even if higher wages are offset by larger commuting and housing costs (from the perspective of the worker) if there were no productivity advantages to urban location, firms would move to low wage location. 
Urban Area, by taking into account density and population as well as commuting patterns (OECD, 2012a). The results are largely self-contained urban labour markets. OECD (2012a) defines 1,148 Functional Urban Areas (FUAs) across 28 OECD member states.

Specifically, municipalities for the EU countries and available lower spatial units for the non-EU countries are used to build up the Functional Urban Areas in a comparable way across countries. The units that include high-density contiguous grids of 1500 inhabitants per square kilometre $\left(\mathrm{km}^{2}\right)$ are designated as "urban cores". The threshold is at 1000 inhabitants per $\mathrm{km}^{2}$ for the United States and Canada. Urban cores that have more than $15 \%$ of their population commuting from one to the other are considered to belong to the same FUA. Less densely populated municipalities that have at least $15 \%$ of their employed population commuting to an urban core are included in the same FUA and form its commuting zone.

To address the concern of non-random sorting of able individuals, a two-step empirical approach is applied separately to national micro-data surveys for the five countries of the study (see Combes, Duranton and Gobillon, 2011, for a theoretical discussion of this methodology). ${ }^{10}$ In the first step, the OECD-EU definition of Functional Urban Areas is applied to large administrative and survey-based micro-data from each of the five countries under study. The resulting data set is used to estimate productivity differentials net of individual skill differences and other individual level observables - across FUAs using an OLS regression of the natural logarithm of wages on individual level characteristics and a set of fixed effects for each FUA in each year. ${ }^{11}$

$$
y_{i a t}=\beta X_{i a t}+\gamma_{a t} d_{i a t}+\varepsilon_{i a t}
$$

$y_{\text {iat }}$ is the natural logarithm of wages for individual $i$ in city $a$ at time $t, X$ is a vector of individual characteristics, $d$ is a vector of dummy variables that take the value 1 if the individual resides in FUA $a$ at time $t$, and $\varepsilon$ an error term. The coefficient of interest, $\gamma_{x}$ captures the productivity differential across cities, net of (observable) skill differences.

Since the primary concern in this study is to create comparable estimates for all five countries (Germany, Mexico, Spain, United Kingdom, and United States), there is a limitation on the specific controls that can be included due to data availability. Not all variables are available in all countries and the samples include both panel data as well as repeated cross-sections. The common set of controls used includes variables for gender, education, experience, occupation, part-timing and city-year fixed effects.

In addition to the above base specification, which is estimated for all five countries, three data sets (Germany, Spain, and United Kingdom) link information for individuals over time and allow for estimating a panel model. For these countries, an additional first stage is estimated that includes individual specific fixed effects $\left(d_{i}\right)$.

$$
y_{\text {iat }}=\beta X_{\text {iat }}+\gamma_{a t} d_{\text {iat }}+\theta_{i} d_{i}+\varepsilon_{\text {iat }}
$$

The advantage of including individual fixed effects is that any time-invariant characteristics that might contribute to an individual's productivity are accounted for, even if these characteristics are not

10. See Combes, Duranton and Gobillon (2008) and Monastiriotis (2002) for earlier implementations of the empirical methodology.

11. This model follows the seminal work by Mincer (1974) and the large body of empirical literature that followed it. The German data is right-censored, which introduces a bias in OLS estimation. However comparing the results from a Tobit model, which accounts for censoring, and the OLS model shows that the bias is negligible (see Ahrend and Lembcke, 2014). 
directly observed (e.g. unobserved ability). Results for this specification are reported in the individual country studies. ${ }^{12}$

The city-year fixed effects obtained from the first stage outlined above denote differential city productivity net of the observable characteristics of the urban workforce. These estimated first-stage differentials $\left(\hat{\gamma}_{\text {at }}\right)$ are used as the dependent variable in the second stage, in which they are regressed on indicators for structural and organisational determinants of city productivity - both time varying $\left(Q_{a t}\right)$ and non-time varying $\left(Z_{a}\right)$. Additional year fixed effects $\left(d_{t}\right)$ control for aggregate business cycles of the national economy and inflation.

$$
\hat{\gamma}_{a t}=\delta Q_{a t}+\mu Z_{a}+\theta d_{t}+u_{a t}
$$

An analogous second stage then pools the comparable first stage estimates in order to examine the impact of structural and organizational factors on a wider number of FUAs. The above specification is then estimated on the pooled sample of all five countries.

$$
\hat{\gamma}_{\text {cat }}=\delta Q_{\text {cat }}+\mu Z_{\text {ca }}+\theta d_{c t}+u_{\text {cat }}
$$

Variables in this pooled regression are defined as in equation (3) except that the country index $c$ is now made explicit. Since inflation rates vary across countries (and the first stage estimates nominal productivity differentials) it is necessary to allow for flexible country time trends. As a result we also include country-year fixed effects $d_{c t}$ in the specification. The OLS estimation is clustered at the FUA level to allow for arbitrary autocorrelation over time in the error term.

In addition to the main specification that restricts the sample to the three years that are available for all five countries (2005-2007), two robustness checks are reported. The first uses all available years such that the sample becomes an unbalanced panel, the second constrains the sample to large metropolitan areas - FUAs with more than 500,000 inhabitants.

There is a range of city characteristics $\left(Q_{\text {cat }}\right.$ and $\left.Z_{c a}\right)$ considered in this study. The five countries' samples are used to construct several city-year indicators that capture city size, industrial structure and human capital. The share of employees working in 1-digit industries, with manufacturing split into four categories based on the sectors technology intensity, and the Herfindahl index of employment shares at the 2-digit industry level are calculated as controls for the industry structure of cities. The Herfindahl index is defined for each FUA as the sum of the squared employment shares in each industry. The samples are also used to estimate the population in each FUA and year. ${ }^{13}$ Furthermore, the share of university degree holders in the 25-64 aged population of the FUA is used as a measure of the human capital. Further description of the data used for each country is provided in Appendix A.

The individual country data is then combined with indicators from the OECD Metropolitan Database on: administrative fragmentation (the number of local governments within a FUA); the presence of a governance body (from Ahrend, Gamper and Schumann, 2014); a dummy variable for the presence of a

12. See Ahrend and Lembcke (2014) for Germany, Georgiadis and Kaplanis (2014) for the United Kingdom, and Diaz and Kaplanis (2014) for Spain. Kaplanis and Tello (2014) reports additional results for Mexico that, however, do not allow for panel estimation.

13. Spain and Germany are exception. For Spain internal OECD estimates for population in the FUA are used. For Germany only total employment can be observed; after the results from the last German census, municipality level population data became unavailable. To estimate population in German FUAs the ratio of employment to population for 2000 is used to scale employment in all years. 
port in the city (based on data from Lloyd's List "Ports"), and the area covered by the FUA (own calculations from different administrative sources). ${ }^{14}$

\section{Empirical results}

Putting numbers to the suggestive trends in the descriptive graphs of Section 2, country by country regressions show productivity to be higher in larger cities across all five countries in this study (Table 1). When city productivity premiums are regressed on population, the estimated elasticities range from 0.016 (for United Kingdom) to 0.063 (for United States). That is, a US city with double the population of another comparable US city is, on average, about $6.3 \%$ more productive. ${ }^{15}$ The main results from the pooled regression, reported in Table 2, present equally strong evidence for sizeable agglomeration benefits. They indicate that, for a doubled population size of a FUA, productivity is by about $3.8 \%$ higher. ${ }^{16}$ The introduction of additional controls for FUA characteristics lead to agglomeration elasticity estimates ranging from 0.02 to 0.05 , with highly statistically significant coefficients in all specifications.

The key focus in this study is the indicator for horizontal governmental fragmentation which is included in Table 2 from the third column onwards. Fragmentation is measured as the natural logarithm of the number of municipalities. ${ }^{17}$ Note that this variable does not need to control for size of the FUA, since the size is already captured by the population density and area covered in the regression. The variable is also implicitly normalized for each country since the empirical specification includes a full set of countryyear fixed effects. The result of the inclusion of this variable is a striking productivity penalty for more fragmented Functional Urban Areas. The estimated coefficient (-0.034) is negative and highly statistically significant. It indicates that between two cities of the same size, in the same country, if one has twice the number of municipalities within its functional boundaries it is on average about $3.4 \%$ less productive. The magnitude of this result remains largely unaffected when further controls are introduced to the estimation. Co-operation and coordination across municipalities, for example in the form of governance bodies, is common across OECD FUAs and can alleviate, to some extent, the problems associated with fragmentation. If this is the case, not explicitly controlling for coordination bodies will result in

14. For the OECD Metropolitan database see: http://dotstat.oecd.org/Index.aspx?Datasetcode=CITIES and http://www.oecd.org/gov/regional-policy/functionalurbanareasbycountry.htm. For port cities see http://directories.lloydslist.com/ accessed 01.07.2013.

15. Interpreting the elasticity multiplied by 100 as the percent increase in productivity associated with a "doubling in city size" is commonly used in the literature to give an idea of the size of the impact. The interpretation is not exact as the ln approximation error is only negligible for small changes. The exact marginal effect for a doubling in city size is the product of the estimated coefficient with $\ln (2) \approx 0.693$.

16. The source of agglomeration benefits can be further disentangled by a specification that uses both population density and surface area of the city. The coefficient of logged population density gives the elasticity of city productivity with respect to population, holding constant the surface area covered by a city. The coefficient on logged city surface area captures the impact of an expansion of city limits while population density remains constant; that is when population and area grow at the same rate. Finally, the difference between the area and the density coefficients gives the estimated impact of increasing the surface area covered by a city while holding the total population constant (i.e. decreasing density with the given population spreading out over a larger surface). Interestingly, coefficients for population and area are similar (Table 2, second column), indicating that both an increased population for a given surface area, and an increased FUA area while population density remains constant, have similar productivity effects. As explained above, it is important to note that the impact of an increase in the spatial extent of a FUA, holding the population constant, is calculated as the difference between these two elasticities. In this specification this difference is zero. This confirms that - for a given population - agglomeration benefits do not increase with the surface area covered by a FUA.

17. Local authority districts for the United Kingdom and counties for the United States. 
underestimates of the true extent of the fragmentation penalty (i.e. the estimated coefficient is too small in absolute value).

Ahrend, Gamper and Schumann (2014) collect information on governance bodies for OECD metropolitan areas, i.e. Functional Urban Areas with at least 500,000 inhabitants. This is a subset of the Functional Urban Areas considered in this study. For this subset of FUAs, information on the presence of a governance body that covers (at least a significant part of) the functional urban area is available. This limits the analysis to 140 cities. While this decrease in the sample size reduces the precision of estimates and the remaining degrees of freedom, especially when the full set of controls is considered, it can nonetheless shed some light on the true impact of fragmentation. ${ }^{18}$

Table 3 reports the impact of horizontal fragmentation in metropolitan areas with and without the presence of a mediating governance body. The impact of horizontal fragmentation is more severe when the presence of governance bodies is taken into account. Without a governance body the negative impact on productivity is about $6 \%$. The fragmentation penalty is halved by the presence of a governance body, in the presence of which a doubled number of municipalities is associated with just $2.5-3 \%$ lower productivity. ${ }^{19}$

Given the small size of the sample it is not possible to consider the impact of fragmentation and governance bodies for each country separately. However, it is possible to use a jackknife approach and reestimate the models excluding one country at a time, which can reveal whether the results are driven by a single country. Table B3 presents the results with each column excluding the metropolitan areas from the indicated country. Without controlling for industry shares the results are qualitatively the same as the main results in Table 3. The weakest impact of administrative fragmentation is found when Mexico is excluded from the model, but even in this case the estimate is 3.2\%. For the remaining subsamples the estimates range from 5-8\% with governance bodies alleviating $40-60 \%$ of the penalty. For completeness the table also reports results that include industry shares, results that suffer from severe identification problems as the number of degrees of freedom in these models becomes very small. ${ }^{20}$

Arguing that coordination is simplified if residents are more concentrated, Cheshire and Magrini (2009) proxy for the degree of fragmentation in urban regions using the proportion of residents living in the largest municipality. Table 4 considers this alternative measure of fragmentation. The results in the first three columns show that concentration of a FUA's inhabitants does indeed appear to ease fragmentation penalties. A 10 percentage point decrease in the share of the population residing in the core municipality is estimated to reduce productivity by $0.5-0.75 \%$ on average. However, when fragmentation indicators are combined into the same specification - columns (IV) through (VI) - horizontal fragmentation measured by the (natural logarithm) of the number of municipalities is very robust and in line with the main estimates, but concentration of residents changes signs and becomes insignificant. Dominance of a single municipality cannot solve the coordination problems raised by fragmentation.

Going back to Table 2 and the remaining indicators, aggregate human capital, measured by the share of university graduates in the city, increases productivity. A ten percentage point increase in the share of

18. A further concern is the comparability and external validity of estimates based solely on metropolitan areas. Table B2 replicates the main estimates in Table 2 for metropolitan areas. The estimated impact of fragmentation is virtually identical.

19. The coefficient on the interaction term indicates the difference in the impact of fragmentation for cities that do have a governance body compared to cities that do not have a governance body. E.g. the marginal effect of an increase in (ln) fragmentation in column (I) of Table 3 is: $-0.057+0.031 \mathrm{x}$ gov.body $-0.057+0.031 \times$ gov. body

20. Standard errors are clustered at the metropolitan area level, which makes the number of metropolitan areas and not the number of observations the base degree of freedom. 
university graduates is associated with a $3 \%$ increase in productivity. It is important to note that this result does not indicate the direct impact of human capital on productivity, but only the externality associated with working in a city with many university graduates. And, while port cities exhibit higher productivity on average port cities are 2-4\% more productive than comparable cities without a port - there appears to be no evidence that capital cities differ systematically from other FUAs.

Industrial specialization, measured by the normalized Herfindahl-Index of employment shares at the 2-digit industry level has a negative impact that is weakly significant. This suggests that a diversified industrial structure has a positive impact on productivity. However, variation in estimates across specifications suggests that this finding is not overly robust. Moreover, clear evidence can be found that cities with a high share of specific industries exhibit higher productivity. The base category in the regressions is the share of employees in construction, such that when an increase in an industry share is considered, the share of employees in construction is reduced by the same amount. The results (column IX in Table 2) indicate that a one percentage point increase in the share of high-tech manufacturing workers (and a concomitant one percentage point decrease in the share of construction workers) is on average associated with a $1.2 \%$ increase in productivity. This productivity premium gradually reduces with the technological intensity of the manufacturing industry: it is $0.82 \%$ and $0.59 \%$ for medium-high-tech and medium-low-tech manufacturing respectively, while it becomes insignificant for low-tech manufacturing. The productivity premium for financial intermediation stands at $0.96 \%$ for a one percentage point increase in the employment share, while that of business services and real estate activity is $0.45 \%$. Interestingly it is not only the knowledge intensive services that yield a productivity premium, but also technology intensive manufacturing.

The final variable considered to determine productivity is the proximity of a Functional Urban Area to other FUAs. Capturing the idea that the exchange of people, ideas and goods is greatly simplified by close connections between places, this variable measures the number of people that citizens of a given FUA can directly interact with in a "reasonable" amount of time (the idea roughly being that a meeting of several hours can take place going back and forth within a day). It is defined as (the natural logarithm) of all inhabitants in other FUAs within a $300 \mathrm{~km}$ radius of a city, divided by the distance. For the sample of all FUAs the estimates in Table 2 indicate that between two comparable cities (in size, share of highly educated workers, degree of horizontal fragmentation, and industry structure), one with twice the number of FUA inhabitants in its proximity, the FUA that is connected to the larger population is about $1-2 \%$ more productive. The estimated coefficients are stable across specifications.

Robustness checks that are comparable to columns (VIII) and (X) of Table 2 are presented in Appendix B. Using the full unbalanced sample (Table B1) and restricting the analysis to only the large FUAs (Table B2) does not affect the main results. Agglomeration benefits are slightly higher when only large Functional Urban Areas are considered, but the size of the standard errors does not allow for any conclusions about a non-linear effect of agglomeration benefits with city size.

\section{Concluding remarks}

This paper estimates productivity differentials of functional urban areas across five OECD countries (Germany, Mexico, Spain, United Kingdom, and United States) and investigates the relationship of urban productivity with the extent of agglomeration and the governance structures prevalent in the functional urban area. It contributes to the literature on agglomeration benefits, by offering a coherent and comparable identification strategy that is applied to micro-data from each of the five OECD countries. The two-step econometric approach adopted in this paper enables the analysis to capture the pure productivity advantages that arise at the city level, accounting for the potential sorting of more productive individuals into certain cities. The comparability of the analysis is supported through the use of an internationally harmonised definition of urban areas according to functional economic linkages rather than administrative 
boundaries. Finally, as far as the authors are aware, this paper represents a first attempt in the literature to empirically examine the relationship between urban governance structure and city productivity across a large number of cities.

In line with the previous literature, the analysis confirms that city productivity premiums tend to increase with city size. Pooled across five OECD countries, estimates indicate that, ceteris paribus, a twofold increase in city size is associated with a $2-5 \%$ increase in productivity. The analysis indicates that urban productivity is also influenced by the population size of nearby cities.

Crucially, this paper identifies a significant role for administrative fragmentation of city structures in determining the magnitude of city productivity premiums. Specifically, for two functional urban areas of similar population and geographical size, but one with twice the number of municipalities, the estimates indicate that the more fragmented FUA has a productivity that is between 3 and $4 \%$ lower. The presence of local governance bodies is found to help Functional Urban Areas to overcome the negative impact of fragmentation. Indeed, results reported in this paper suggest that the 3-4\% estimate may be a lower bound on the estimate of the impact of governmental fragmentation, with the true fragmentation penalty lying around $6 \%$.

While the presence of an area wide governance body is found to mitigate the negative effect of fragmentation by roughly half, little is known about the underlying transmission mechanisms from administrative fragmentation to stymied productivity. The influence of administrative fragmentation may stem from a variety of associated factors; it may, for example be related to less efficient transport systems or to sub-optimal land use due to a lack of coordination in more fragmented urban areas. However, a full examination of the causes of lower productivity in more administratively fragmented urban areas will require more detailed information on urban governance structures.

\section{Acknowledgement:}

This work contains UK statistical data from ONS which is Crown copyright and reproduced with the permission of the controller of HMSO and Queen's Printer for Scotland. The use of the ONS statistical data in this work does not imply the endorsement of the ONS in relation to the interpretation or analysis of the statistical data. This work uses research datasets which may not exactly reproduce National Statistics aggregates. This study also uses the German weakly anonymous BA-Employment Panel (version 19982007). Data access was provided via remote data access. 
Table 1. Regressions from individual country regressions

\begin{tabular}{|c|c|c|c|c|c|c|c|c|c|c|}
\hline & UK & Spain & Germany & US & Mexico & UK & Spain & Germany & US & Mexico \\
\hline \multirow[t]{2}{*}{ In(population) } & $0.016^{*}$ & $0.034^{\star * *}$ & $0.037^{\star \star \star}$ & $0.063^{\star \star \star}$ & $0.042^{\star \star}$ & & & & & \\
\hline & $(0.009)$ & $(0.012)$ & $(0.010)$ & $(0.008)$ & $(0.020)$ & & & & & \\
\hline \multirow[t]{2}{*}{ In(pop.density) } & & & & & & 0.009 & $0.046^{\star * *}$ & $0.068^{\star * *}$ & $0.066^{* * *}$ & 0.022 \\
\hline & & & & & & $(0.009)$ & $(0.011)$ & $(0.010)$ & $(0.009)$ & $(0.019)$ \\
\hline \multirow[t]{2}{*}{$\ln ($ area $)$} & & & & & & $0.019^{*}$ & $0.032^{\star \star}$ & $0.020^{\star *}$ & $0.058^{* * *}$ & $0.083^{\star \star *}$ \\
\hline & & & & & & $(0.01)$ & $(0.013)$ & $(0.009)$ & $(0.010)$ & $(0.021)$ \\
\hline R-squared & 0.666 & 0.294 & 0.191 & 0.914 & 0.483 & 0.649 & 0.314 & 0.328 & 0.915 & 0.569 \\
\hline Year FE & Yes & Yes & Yes & Yes & Yes & Yes & Yes & Yes & Yes & Yes \\
\hline Observations & 808 & 532 & 981 & 345 & 825 & 808 & 532 & 981 & 345 & 825 \\
\hline FUAs & 101 & 76 & 109 & 69 & 75 & 101 & 76 & 109 & 69 & 75 \\
\hline
\end{tabular}

Notes: Table reports OLS regressions with estimated Functional Urban Area (FUA) productivity as dependent variable. FUA productivity is estimated by applying individual wage regressions to national micro-data in order to control for workforce composition of cities. Log hourly wages/earnings are regressed on gender, experience, education, occupation and city-year dummies; the coefficients of the latter are taken to denote productivity differentials. (see text for details). Variable definitions in section 4. Standard errors are clustered at the Functional Urban Area level, all specifications include time fixed effects.

Data sources: UK: ASHE/LFS; Spain: MCVL; Germany: IAB; US: IPUMS; Mexico: ENE/ENOE

$* * * / * / *$ indicates a statistically significant coefficient at the $1 \% / 5 \% / 10 \%$ level

Sample years are: 2003-2010 (UK); 2005-2011 (Spain); 1999-2007 (Germany); 1990, 2000, 2005-2007 (US); $2000-2010$ (Mexico). 
Table 2. Pooled regressions: common years (2005-2007)

\begin{tabular}{|c|c|c|c|c|c|c|c|c|c|c|}
\hline & (I) & (III) & (IIII) & (IV) & (V) & $(\mathrm{VI})$ & (VII) & (VIII) & (IX) & $(\mathrm{X})$ \\
\hline In(population) & $\begin{array}{l}0.038^{* \star *} \\
(0.005)\end{array}$ & & & & & & & & & \\
\hline In(density) & & $\begin{array}{c}0.038^{\star * *} \\
(0.006)\end{array}$ & $\begin{array}{c}0.048^{\star * \star} \\
(0.006)\end{array}$ & $\begin{array}{c}0.045^{\star \star \star} \\
(0.006)\end{array}$ & $\begin{array}{c}0.042^{* \star *} \\
(0.006)\end{array}$ & $\begin{array}{c}0.043^{\star \star \star} \\
(0.006)\end{array}$ & $\begin{array}{c}0.037^{\star \star \star} \\
(0.007)\end{array}$ & $\begin{array}{c}0.034^{\star \star \star} \\
(0.007)\end{array}$ & $\begin{array}{c}0.018^{\star \star \star} \\
(0.007)\end{array}$ & $\begin{array}{l}0.016^{* *} \\
(0.007)\end{array}$ \\
\hline In(area) & & $\begin{array}{l}0.038^{\star \star *} \\
(0.006)\end{array}$ & $\begin{array}{l}0.064^{* * *} \\
(0.008)\end{array}$ & $\begin{array}{c}0.070^{* * *} \\
(0.009)\end{array}$ & $\begin{array}{c}0.066^{* * *} \\
(0.009)\end{array}$ & $\begin{array}{c}0.066^{* * *} \\
(0.009)\end{array}$ & $\begin{array}{c}0.062^{* * *} \\
(0.009)\end{array}$ & $\begin{array}{c}0.058^{\star * *} \\
(0.010)\end{array}$ & $\begin{array}{c}0.039^{\star * *} \\
(0.008)\end{array}$ & $\begin{array}{c}0.036^{\star * *} \\
(0.008)\end{array}$ \\
\hline In(municipalit.) & & & $\begin{array}{l}-0.032^{* * *} \\
(0.006)\end{array}$ & $\begin{array}{l}-0.035^{\star \star *} \\
(0.006)\end{array}$ & $\begin{array}{c}-0.037^{\star * *} \\
(0.006)\end{array}$ & $\begin{array}{c}-0.037^{\star * *} \\
(0.006)\end{array}$ & $\begin{array}{c}-0.036^{\star * *} \\
(0.006)\end{array}$ & $\begin{array}{c}-0.036^{\star \star *} \\
(0.006)\end{array}$ & $\begin{array}{c}-0.029^{* \star \star} \\
(0.005)\end{array}$ & $\begin{array}{c}-0.029^{\star * *} \\
(0.005)\end{array}$ \\
\hline $\begin{array}{l}\text { In(pop. in } \\
\text { catchment area) }\end{array}$ & & & & $\begin{array}{l}0.017^{\star *} \\
(0.008)\end{array}$ & $\begin{array}{l}0.015^{\star} \\
(0.008)\end{array}$ & $\begin{array}{l}0.015^{*} \\
(0.008)\end{array}$ & $\begin{array}{l}0.018^{* *} \\
(0.008)\end{array}$ & $\begin{array}{l}0.017^{* *} \\
(0.008)\end{array}$ & $\begin{array}{l}0.013^{*} \\
(0.007)\end{array}$ & $\begin{array}{l}0.012^{*} \\
(0.007)\end{array}$ \\
\hline $\begin{array}{l}\% \text { university } \\
\text { graduates }\end{array}$ & & & & & $\begin{array}{l}0.273^{\star \star *} \\
(0.077)\end{array}$ & $\begin{array}{c}0.275^{\star * *} \\
(0.077)\end{array}$ & $\begin{array}{c}0.283^{* * *} \\
(0.077)\end{array}$ & $\begin{array}{c}0.258^{* * *} \\
(0.075)\end{array}$ & $\begin{array}{c}0.287^{* * *} \\
(0.076)\end{array}$ & $\begin{array}{l}0.275^{\star * *} \\
(0.073)\end{array}$ \\
\hline Capital & & & & & & $\begin{array}{l}-0.017 \\
(0.042)\end{array}$ & $\begin{array}{l}-0.011 \\
(0.037)\end{array}$ & $\begin{array}{l}-0.000 \\
(0.038)\end{array}$ & $\begin{array}{c}0.019 \\
(0.030)\end{array}$ & $\begin{array}{c}0.028 \\
(0.030)\end{array}$ \\
\hline Port & & & & & & & $\begin{array}{l}0.027^{\star *} \\
(0.011)\end{array}$ & $\begin{array}{l}0.027^{* *} \\
(0.011)\end{array}$ & $\begin{array}{c}0.038^{* * *} \\
(0.010)\end{array}$ & $\begin{array}{c}0.039^{* \star *} \\
(0.010)\end{array}$ \\
\hline $\begin{array}{l}\text { Herfindahl } \\
\text { index }\end{array}$ & & & & & & & & $\begin{array}{l}-0.698^{*} \\
(0.358)\end{array}$ & & $\begin{array}{c}-0.704^{* * *} \\
(0.266)\end{array}$ \\
\hline Agriculture & & & & & & & & & $\begin{array}{c}0.085 \\
(0.253)\end{array}$ & $\begin{array}{l}0.0808 \\
(0.257)\end{array}$ \\
\hline $\begin{array}{l}\text { High-tech } \\
\text { manufacturing }\end{array}$ & & & & & & & & & $\begin{array}{l}1.176^{* * *} \\
(0.227)\end{array}$ & $\begin{array}{l}1.104^{\star \star \star} \\
(0.234)\end{array}$ \\
\hline $\begin{array}{l}\text { Med. high-tech } \\
\text { manufacturing }\end{array}$ & & & & & & & & & $\begin{array}{c}0.824^{\star * \star *} \\
(0.140)\end{array}$ & $\begin{array}{c}0.840^{\star \star *} \\
(0.135)\end{array}$ \\
\hline Med. low-tech & & & & & & & & & $0.591^{* * *}$ & $0.494^{\star * \star}$ \\
\hline manufacturing & & & & & & & & & $(0.146)$ & $(0.146)$ \\
\hline Low-tech & & & & & & & & & 0.069 & 0.082 \\
\hline manufacturing & & & & & & & & & $(0.161)$ & $(0.149)$ \\
\hline Electricity & & & & & & & & & $\begin{array}{l}-0.812^{*} \\
(0.454)\end{array}$ & $\begin{array}{l}-0.931^{\star *} \\
(0.463)\end{array}$ \\
\hline Trade & & & & & & & & & $\begin{array}{c}0.229 \\
(0.174)\end{array}$ & $\begin{array}{c}0.223 \\
(0.171)\end{array}$ \\
\hline Catering & & & & & & & & & $\begin{array}{c}0.381 \\
(0.259)\end{array}$ & $\begin{array}{l}0.472^{\star *} \\
(0.230)\end{array}$ \\
\hline $\begin{array}{l}\text { Transport \& } \\
\text { communication }\end{array}$ & & & & & & & & & $\begin{array}{c}0.002 \\
(0.193)\end{array}$ & $\begin{array}{l}-0.126 \\
(0.200)\end{array}$ \\
\hline Finance & & & & & & & & & $\begin{array}{c}0.955^{\star \star *} \\
(0.176)\end{array}$ & $\begin{array}{l}0.878^{\star \star \star} \\
(0.181)\end{array}$ \\
\hline Real estate & & & & & & & & & $0.449^{\star \star}$ & $0.410^{* *}$ \\
\hline \& business & & & & & & & & & $(0.183)$ & $(0.176)$ \\
\hline Public & & & & & & & & & 0.079 & 0.057 \\
\hline administration & & & & & & & & & $(0.260)$ & $(0.261)$ \\
\hline Educ., health & & & & & & & & & -0.100 & -0.120 \\
\hline \& social work & & & & & & & & & $(0.157)$ & $(0.154)$ \\
\hline Other services & & & & & & & & & $\begin{array}{l}0.561^{* *} \\
(0.276)\end{array}$ & $\begin{array}{l}0.535^{\star} \\
(0.275)\end{array}$ \\
\hline R-Squared & 0.760 & 0.760 & 0.779 & 0.783 & 0.788 & 0.788 & 0.791 & 0.794 & 0.852 & 0.854 \\
\hline Observations & 1,290 & 1,290 & 1,290 & 1,290 & 1,290 & 1,290 & 1,290 & 1,290 & 1,290 & 1,290 \\
\hline FUAs & 430 & 430 & 430 & 430 & 430 & 430 & 430 & 430 & 430 & 430 \\
\hline
\end{tabular}

Notes and data sources: see Table 1

Includes an interaction control of country and year fixed effects (Country x Year FE).

${ }^{* * *} / * * /{ }^{*}$ indicates a statistically significant coefficient at the $1 \% / 5 \% / 10 \%$ level. 
Table 3. Pooled regressions on governance indicators (2005-2007)

\begin{tabular}{|c|c|c|c|}
\hline & (I) & (II) & (III) \\
\hline \multirow[t]{2}{*}{ In(density) } & $0.065^{\star * *}$ & $0.047^{\star * *}$ & $0.035^{\star * *}$ \\
\hline & $(0.012)$ & $(0.012)$ & $(0.011)$ \\
\hline \multirow[t]{2}{*}{ In(area) } & $0.085^{\star * *}$ & $0.087^{\star \star \star}$ & $0.070^{\star \star \star *}$ \\
\hline & $(0.012)$ & $(0.013)$ & $(0.014)$ \\
\hline \multirow[t]{2}{*}{ In(municipalit.) } & $-0.057^{\star \star \star}$ & $-0.066^{\star \star \star}$ & $-0.033^{\star * \star}$ \\
\hline & $(0.016)$ & $(0.017)$ & $(0.013)$ \\
\hline In(municipalit.) & $0.031^{* *}$ & $0.036^{* *}$ & 0.006 \\
\hline X govern. body & $(0.014)$ & $(0.015)$ & $(0.011)$ \\
\hline Governance & $-0.079^{\star *}$ & $-0.092^{* *}$ & -0.024 \\
\hline Body & $(0.034)$ & $(0.038)$ & $(0.027)$ \\
\hline $\ln$ (pop. in & & $0.022^{\star \star}$ & 0.013 \\
\hline catchment area) & & $(0.010)$ & $(0.008)$ \\
\hline$\%$ university & & $0.478^{\star \star \star}$ & $0.390^{\star *}$ \\
\hline graduates & & $(0.138)$ & $(0.152)$ \\
\hline \multirow[t]{2}{*}{ Capital } & & -0.025 & -0.045 \\
\hline & & $(0.040)$ & $(0.030)$ \\
\hline \multirow[t]{2}{*}{ Port } & & $0.025^{\star}$ & $0.031^{\star \star *}$ \\
\hline & & $(0.013)$ & $(0.010)$ \\
\hline Herfindahl & & -1.136 & 0.349 \\
\hline index & & $(1.328)$ & $(0.858)$ \\
\hline \multirow[t]{2}{*}{ Agriculture } & & & 0.429 \\
\hline & & & $(0.547)$ \\
\hline High-tech & & & $0.998^{\star \star}$ \\
\hline manufacturing & & & $(0.450)$ \\
\hline Med. high-tech & & & $1.052^{* \star *}$ \\
\hline manufacturing & & & $(0.344)$ \\
\hline Med. low-tech & & & $2.003^{\star \star *}$ \\
\hline manufacturing & & & $(0.544)$ \\
\hline Low-tech & & & $1.076^{\star \star *}$ \\
\hline manufacturing & & & $(0.352)$ \\
\hline \multirow[t]{2}{*}{ Electricity } & & & -0.412 \\
\hline & & & (1.433) \\
\hline \multirow[t]{2}{*}{ Trade } & & & 0.704 \\
\hline & & & $(0.480)$ \\
\hline \multirow[t]{2}{*}{ Catering } & & & 0.130 \\
\hline & & & $(0.729)$ \\
\hline Transport \& & & & -0.0766 \\
\hline communication & & & $(0.583)$ \\
\hline \multirow[t]{2}{*}{ Finance } & & & $1.668^{* \star *}$ \\
\hline & & & $(0.420)$ \\
\hline Real estate & & & 0.420 \\
\hline \& business & & & $(0.487)$ \\
\hline Public & & & $1.023^{* *}$ \\
\hline administration & & & $(0.445)$ \\
\hline Educ., health & & & -0.113 \\
\hline \& social work & & & $(0.341)$ \\
\hline \multirow[t]{2}{*}{ Other services } & & & $2.265^{* \star *}$ \\
\hline & & & $(0.491)$ \\
\hline R-Squared & 0.855 & 0.880 & 0.929 \\
\hline Observations & 420 & 420 & 420 \\
\hline FUAs & 140 & 140 & 140 \\
\hline
\end{tabular}


Table 4. Robustness checks with alternative fragmentation indicators (2005-2007)

\begin{tabular}{|c|c|c|c|c|c|c|}
\hline & (I) & (II) & (III) & (IV) & (V) & $=(\mathrm{VI})$ \\
\hline \multirow[t]{2}{*}{ In(density) } & $0.041^{* \star \star}$ & $0.030^{* \star *}$ & $0.014^{*}$ & $0.046^{\star \star \star}$ & $0.031^{* \star *}$ & $0.016^{\star \star}$ \\
\hline & $(0.006)$ & $(0.008)$ & $(0.007)$ & $(0.006)$ & $(0.007)$ & $(0.007)$ \\
\hline \multirow[t]{2}{*}{ In(area) } & $0.042^{\star \star \star}$ & $0.034^{\star * *}$ & $0.020^{\star \star \star}$ & $0.065^{\star \star \star}$ & $0.058^{\star \star *}$ & $0.036^{\star \star \star}$ \\
\hline & $(0.007)$ & $(0.009)$ & $(0.007)$ & $(0.008)$ & $(0.010)$ & $(0.008)$ \\
\hline \multirow[t]{2}{*}{ In(municipalit.) } & & & & $-0.039^{* * *}$ & $-0.044^{* * *}$ & $-0.031^{\star \star *}$ \\
\hline & & & & $(0.007)$ & $(0.007)$ & $(0.006)$ \\
\hline$\%$ of pop.in & $0.053^{*}$ & $0.058^{*}$ & $0.075^{\star * *}$ & $-0.064^{*}$ & $-0.069^{\star *}$ & -0.013 \\
\hline largest municip. & $(0.031)$ & $(0.030)$ & $(0.025)$ & $(0.036)$ & $(0.034)$ & $(0.029)$ \\
\hline $\ln ($ pop. in & & 0.011 & 0.009 & & $0.017^{* *}$ & $0.012^{*}$ \\
\hline catchment area) & & $(0.008)$ & $(0.007)$ & & $(0.008)$ & $(0.007)$ \\
\hline$\%$ university & & $0.212^{* * *}$ & $0.285^{\star \star *}$ & & $0.250^{* * *}$ & $0.270^{\star * *}$ \\
\hline graduates & & $(0.078)$ & $(0.074)$ & & $(0.073)$ & $(0.074)$ \\
\hline \multirow[t]{2}{*}{ Capital } & & -0.0324 & 0.003 & & 0.008 & 0.029 \\
\hline & & $(0.043)$ & $(0.035)$ & & $(0.034)$ & $(0.029)$ \\
\hline \multirow[t]{2}{*}{ Port } & & $0.033^{* * *}$ & $0.044^{\star * *}$ & & $0.027^{* *}$ & $0.039^{\star * *}$ \\
\hline & & $(0.012)$ & $(0.010)$ & & $(0.011)$ & $(0.010)$ \\
\hline Herfindahl & & $-0.614^{*}$ & $-0.616^{\star \star}$ & & $-0.741^{\star \star}$ & $-0.710^{\star \star \star}$ \\
\hline index & & $(0.345)$ & $(0.268)$ & & $(0.356)$ & $(0.268)$ \\
\hline \multirow[t]{2}{*}{ Agriculture } & & & 0.159 & & & 0.077 \\
\hline & & & $(0.265)$ & & & $(0.257)$ \\
\hline High-tech & & & $1.236^{\star \star \star}$ & & & $1.096^{\star * *}$ \\
\hline manufacturing & & & $(0.250)$ & & & $(0.238)$ \\
\hline Med. high-tech & & & $0.867^{\star * *}$ & & & $0.834^{* * *}$ \\
\hline manufacturing & & & $(0.134)$ & & & $(0.137)$ \\
\hline Med. low-tech & & & $0.654^{\star * *}$ & & & $0.486^{\star * *}$ \\
\hline manufacturing & & & $(0.149)$ & & & $(0.147)$ \\
\hline Low-tech & & & 0.0705 & & & 0.078 \\
\hline manufacturing & & & $(0.146)$ & & & $(0.151)$ \\
\hline \multirow[t]{2}{*}{ Electricity } & & & $-0.836^{*}$ & & & $-0.935^{\star *}$ \\
\hline & & & $(0.471)$ & & & $(0.465)$ \\
\hline \multirow[t]{2}{*}{ Trade } & & & $0.319^{*}$ & & & 0.219 \\
\hline & & & $(0.172)$ & & & $(0.172)$ \\
\hline \multirow[t]{2}{*}{ Catering } & & & $0.531^{* *}$ & & & $0.467^{* *}$ \\
\hline & & & $(0.232)$ & & & $(0.232)$ \\
\hline Transport \& & & & -0.215 & & & -0.124 \\
\hline communication & & & $(0.206)$ & & & $(0.200)$ \\
\hline \multirow[t]{2}{*}{ Finance } & & & $0.887^{* * *}$ & & & $0.872^{* * *}$ \\
\hline & & & $(0.181)$ & & & $(0.180)$ \\
\hline Real estate & & & $0.411^{\star *}$ & & & $0.418^{\star *}$ \\
\hline$\&$ business & & & $(0.182)$ & & & $(0.177)$ \\
\hline Public & & & 0.103 & & & 0.0517 \\
\hline administration & & & $(0.255)$ & & & $(0.266)$ \\
\hline Educ., health & & & -0.171 & & & -0.117 \\
\hline \& social work & & & $(0.157)$ & & & $(0.153)$ \\
\hline \multirow[t]{2}{*}{ Other services } & & & $0.591^{* *}$ & & & $0.532^{*}$ \\
\hline & & & $(0.275)$ & & & $(0.278)$ \\
\hline R-Squared & 0.762 & 0.774 & 0.845 & 0.781 & 0.796 & 0.854 \\
\hline Observations & 1,290 & 1,290 & 1,290 & 1,290 & 1,290 & 1,290 \\
\hline FUAs & 430 & 430 & 430 & 430 & 430 & 430 \\
\hline
\end{tabular}

Notes and data sources: see Table 1

Includes an interaction control of country and year fixed effects (Country x Year FE).

$* * * / * *{ }^{*}$ indicates a statistically significant coefficient at the $1 \% / 5 \% / 10 \%$ level. 


\section{APPENDIX A. DATA DESCRIPTION FOR INDIVIDUAL COUNTRIES}

\section{United Kingdom}

The estimation of the first-stage is based on data from the UK Annual Survey of Hours and Earnings (ASHE) for 2003-2010. ASHE is the largest survey on labour market statistics with approximately 160,000 employees a year. It is a random sample of around $1 \%$ of the National Insurance pool, as it tracks employees whose national insurance ends with a specific pair of digits. The information is collected by questionnaires sent to employers in April each year, with questions on wages, job and individual workers characteristics. It is an unbalanced panel as individuals can be followed over time, but would drop from the survey if they become unemployed or move to self-employment. The sample is restricted to main jobs only.

ASHE provides detailed information on individual earnings and hours worked and for our analysis we use gross hourly earnings as our wage measure. Additional information on individual characteristics includes occupation, industry, whether the job is in the private or public sector, the worker's age and gender. Information on education is not available via ASHE and thus we have to impute education using the UK Quarterly Labour Force Survey for 2003-2010. Specifically, an individual's years of schooling in ASHE are simulated using estimates of the coefficients of the Best Linear Predictor of education from the Labour Force survey over the same period. ${ }^{21}$ Quarterly Labour Force Survey (QLFS) is also used to construct most of the city controls of the second stage, like population, the share of university graduates, Herfindahl Index (2-digit SIC2003) and the various industrial shares. A more detailed description of the data used is offered in Georgiadis and Kaplanis (2014).

\section{Spain}

For the empirical analysis, the Muestra Continua de Vidas Laborales, MCVL, (Continuous sample of working histories), an administrative data set provided by the Social Security Administration is used. The recently released MCVL contains information of individuals who had an active record with the Social Security system at any time during the years 2005-2011. Each year the sample is a $4 \%$ non-stratified random draw from a reference population that includes employed workers (wage earners and selfemployed), unemployment benefits recipients and pension earners. It consists of nearly 1.1 million individuals per year. The MCVL tries to reconstruct the employment and contribution history of the selected individuals. The information available on labour histories dates back to 1967 while earnings records are tracked since 1980.

Individuals that are registered in the Social Security as wage earners between 2006 and 2011 are selected and their working histories are used to construct most of the individual variables of the first stage. Since 2006, the MCVL can be matched with the tax records, which contains the summary for each fiscal

21. In particular, education was simulated using coefficients' estimates of regressions of education on year of birth and year of birth squared separately by two-digit occupation in the Quarterly LFS (2003-2010) and information on year of birth and two-digit occupation code in ASHE. Other studies based in ASHE use occupation controls as proxies for education arguing that the former is a fairly good proxy for the latter (Kaplanis, 2010; Gibbons, Overman and Pelkonen, 2010). 
year of all the withholdings and prepayments of personal income tax on earned income, economic activities, prizes and income imputations. Since, the aim is to investigate issues related to wages, this data is suitable as this category of income is well represented by the reliability and the general scope of the tax data for earned income. These tax records allow the construction of an annual panel covering the period 2005-2011, with very precise information about individual earnings. Therefore all individual wages for all workers in the MCVL for that period are accounted for. In order to have the maximum number of observation the tax records are merged for all the available years, i.e. 2005-2011. The analysis is restricted to wage earners, self-employed are left out of the sample.

The OECD defines 76 FUAs in Spain, which represents about $62 \%$ of the Spanish population. In the MCVL, only municipalities with more than 40,000 inhabitants can be identified. For a detailed description of the necessary adjustments in order to construct FUAs well as further information on the variables used in the regressions, the reader should refer to the relevant OECD working paper (Diaz, forthcoming).

\section{Germany}

For the German individual level regressions the Employment Panel of the German Federal Employment Agency (BA) hosted by the Research Data Centre (FDZ) at the Institute for Employment Research (IAB) is used. ${ }^{22}$ The data contains a $2 \%$ sample of all registered employees who are subject to social security contributions on the reference date. The sample is a panel data set that covers the years from 1998 to 2007 and the on-site version of the data set contains information on the municipality (Gemeinde) of residence. ${ }^{23}$

The data does not contain information on hours worked (other than part-time status). It is therefore necessary to estimate earnings- rather than wage differentials across FUAs. As controls gender, age (and its square), educational attainment, occupational standing (apprentice, white or blue collar, master craftsmen, etc.: 7 categories), and occupation (3-digit) are added.

\section{United States}

For the United States of America the sample combines the U.S. Census from 1990 and 2000 with the American Community Survey for the years 2005 to 2007. The data are provided as a scientific use-file by the IPUMS project. ${ }^{24}$ The available information on county of residence is used to link the IPUMS data with the OECD (2012a) definition of Functional Urban Areas. Since not all counties are identified in the scientific use-file, the metropolitan statistical area/s (MSAs) that coincide with a FUA is identified and observations from those MSAs are added. The resulting IPUMS based estimates for FUA size are close to the corresponding OECD calculations.

To estimate the wage equations hourly wages are constructed as the sum of all earnings from wages in the last year divided by the product of the number of hours usually worked per week in the previous year and the number of weeks worked. The estimates include controls for part-time status (using the Bureau of Labor Statistics definition of usually working less than 35 hours per week), gender, educational attainment, age and its square, and occupation (3-digit codes). Sampling weights are used in all calculations.

\section{Mexico}

The data refer to 2000-2010 and come from the Labour Force Surveys (National Occupation and Employment Survey, ENOE and the National Employment Survey, ENE), carried out by the National

22. See Schmucker and Seth (2009) for a detailed description of the data.

23. The sample changes slightly in 1999. The study is therefore limited to the years 1999-2007.

24. Ruggles et al. (2010). 
Institute of Statistics and Geography of Mexico (INEGI). Data from 2000 to 2004 are derived from the National Employment Survey (ENE) and from 2005 to 2010 data refer to the National Occupation and Employment Survey (ENOE). Both are household surveys, whose selection units are dwellings selected by sample techniques.

The Mexican labour force surveys (ENE and ENOE) are representative of urban and rural areas, as well for each of the 32 Mexican States, include a quarterly rotating panel of survey respondents, and is a rotating panel (rotation scheme of $20 \%$, i.e., workers are observed at most five times over a five-quarter period).

The data provide information on both economically active (labour force) and non-economically active population and is referred to persons aged 15 years old onwards. The surveys cover social and demographic information and provide details about job characteristics, incomes, work duration, demographics and education. Schooling was aggregate in five categories: no schooling or incomplete primary; complete primary; lower secondary; upper secondary and higher or tertiary. The data contain a monthly earnings variable from which we calculate logarithmic hourly wages as the ratio of monthly earnings to 4.3 times the hours worked weekly. For individuals who report their wages as a multiple of the minimum wage, we assign as their wage the mean of the interval.

Additional city controls that are not from ENE or ENOE, have also been used. For city population we use information from the Census for the years 2000, 2005 and 2010 and interpolate the intermediate years. (Source: INEGI, General Census of Population and Housing, 2000, 2005 and 2010). For the land area, the data come from the Mexican Statistical Office, INEGI (Cartography of land use and vegetation 2002 and 2005). Finally, port data come from the Mexican Ministry of Transportation and Communications (STC), through the General Coordination of Seaports and Merchant Marine. 


\section{APPENDIX B. ADDITIONAL FIGURES AND TABLES}

Figure B1. Population size and labour productivity by city

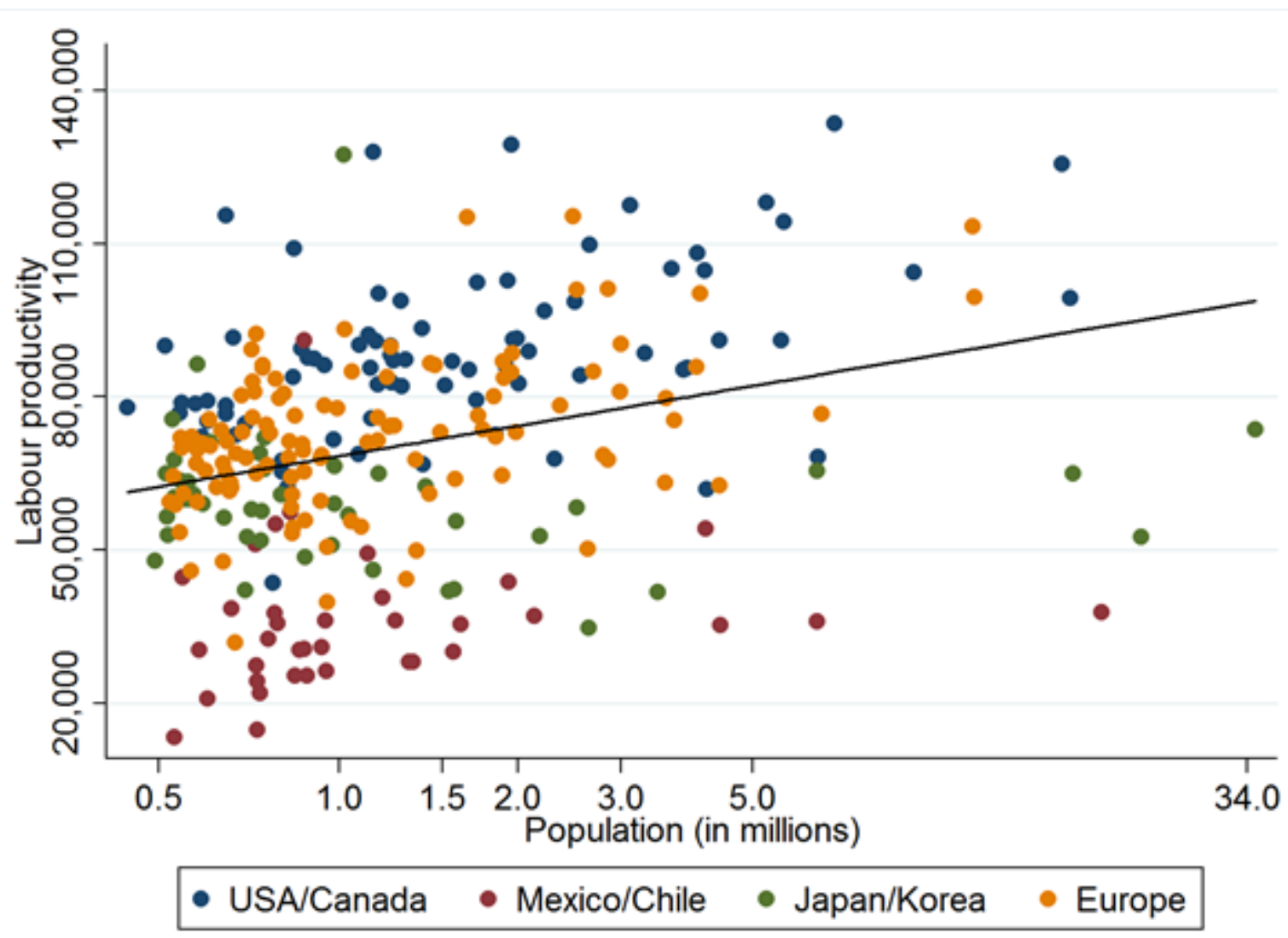

Notes: Labour Productivity is measured as GDP (Millions of US\$ constant PPP, constant prices, reference year is 2005) divided by the total number of employees in a Functional Urban Area. Data refer to 2010 or the closest available year.

Source: OECD Metropolitan Explorer. 
Table B1. Pooled estimation (all years)

\begin{tabular}{|c|c|c|c|c|}
\hline & (I) & (II) & (IIII) & (IV) \\
\hline \multirow[t]{2}{*}{ In(density) } & $0.039^{* \star *}$ & $0.016^{*}$ & $0.058^{\star \star \star}$ & $0.041^{\star \star \star}$ \\
\hline & $(0.009)$ & $(0.009)$ & $(0.015)$ & $(0.012)$ \\
\hline \multirow[t]{2}{*}{ In(area) } & $0.074^{\star \star *}$ & $0.044^{\star \star *}$ & $0.113^{\star \star \star}$ & $0.082^{\star \star \star}$ \\
\hline & $(0.011)$ & $(0.010)$ & $(0.016)$ & $(0.014)$ \\
\hline \multirow[t]{2}{*}{ In(municipalit.) } & $-0.045^{\star \star *}$ & $-0.037^{\star \star \star}$ & $-0.080^{\star \star *}$ & $-0.043^{\star * *}$ \\
\hline & $(0.006)$ & $(0.006)$ & $(0.021)$ & $(0.016)$ \\
\hline $\ln$ (municipalit.) & & & $0.040^{* *}$ & 0.003 \\
\hline$X$ govern. body & & & $(0.018)$ & $(0.013)$ \\
\hline Governance & & & $-0.101^{\star *}$ & -0.018 \\
\hline body & & & $(0.048)$ & $(0.034)$ \\
\hline $\ln$ (pop. in & $0.019^{\star *}$ & 0.013 & $0.027^{\star *}$ & 0.014 \\
\hline catchment area) & $(0.009)$ & $(0.008)$ & $(0.012)$ & $(0.009)$ \\
\hline$\%$ university & 0.106 & $0.181^{* *}$ & $0.355^{*}$ & $0.373^{*}$ \\
\hline graduates & $(0.078)$ & $(0.077)$ & $(0.181)$ & $(0.206)$ \\
\hline \multirow[t]{2}{*}{ Capital } & -0.009 & 0.032 & -0.044 & -0.022 \\
\hline & $(0.037)$ & $(0.028)$ & $(0.049)$ & $(0.039)$ \\
\hline \multirow[t]{2}{*}{ Port } & 0.023 & $0.038^{\star \star *}$ & 0.013 & $0.025^{\star \star}$ \\
\hline & $(0.014)$ & $(0.011)$ & $(0.020)$ & $(0.012)$ \\
\hline Herfindahl & -0.440 & $-0.588^{* *}$ & 0.028 & 0.353 \\
\hline index & $(0.328)$ & $(0.234)$ & (1.120) & $(0.648)$ \\
\hline \multirow[t]{2}{*}{ Agriculture } & & -0.008 & & 0.049 \\
\hline & & $(0.226)$ & & $(0.453)$ \\
\hline High-tech & & $1.241^{\star \star *}$ & & $1.528^{\star \star}$ \\
\hline manufacturing & & $(0.264)$ & & $(0.640)$ \\
\hline Med. high-tech & & $0.861^{\star * *}$ & & $0.898^{* *}$ \\
\hline manufacturing & & $(0.138)$ & & $(0.361)$ \\
\hline Med. low-tech & & $0.448^{* * *}$ & & $2.106^{\star * *}$ \\
\hline manufacturing & & $(0.153)$ & & $(0.560)$ \\
\hline Low-tech & & 0.155 & & $0.808^{* *}$ \\
\hline manufacturing & & $(0.172)$ & & $(0.380)$ \\
\hline \multirow[t]{2}{*}{ Electricity } & & -0.646 & & -0.392 \\
\hline & & $(0.424)$ & & (1.404) \\
\hline \multirow[t]{2}{*}{ Trade } & & 0.116 & & 0.242 \\
\hline & & $(0.159)$ & & $(0.446)$ \\
\hline \multirow[t]{2}{*}{ Catering } & & $0.392^{* *}$ & & 0.227 \\
\hline & & $(0.190)$ & & $(0.782)$ \\
\hline Transport \& & & -0.142 & & -0.333 \\
\hline communication & & $(0.210)$ & & $(0.581)$ \\
\hline \multirow[t]{2}{*}{ Finance } & & $0.785^{\star * \star}$ & & $1.852^{\star \star *}$ \\
\hline & & $(0.205)$ & & $(0.475)$ \\
\hline Real estate & & $0.488^{* * *}$ & & 0.183 \\
\hline$\&$ business & & $(0.179)$ & & $(0.572)$ \\
\hline Public & & 0.140 & & $1.017^{\star \star}$ \\
\hline administration & & $(0.232)$ & & $(0.512)$ \\
\hline Education health & & -0.155 & & -0.370 \\
\hline social work & & $(0.155)$ & & $(0.397)$ \\
\hline \multirow[t]{2}{*}{ Other services } & & 0.300 & & $0.992^{*}$ \\
\hline & & $(0.260)$ & & $(0.509)$ \\
\hline R-Squared & 0.708 & 0.794 & 0.847 & 0.906 \\
\hline Observations & 3,390 & 3,390 & 996 & 996 \\
\hline FUAs & 430 & 430 & 140 & 140 \\
\hline
\end{tabular}

Notes and data sources: see Table 1

Includes an interaction control of country and year fixed effects (Country $x$ Year FE).

$* * * / * * / *$ indicates a statistically significant coefficient at the $1 \% / 5 \% / 10 \%$ level

Sample years are: 2003-2010 (UK); 2005-2011 (Spain); 1999-2007 (Germany); 1990, 2000, 2005-2007 (US); $2000-2010$ (Mexico) 
Table B2. Pooled estimation for metropolitan areas only (2005-2007)

\begin{tabular}{|c|c|c|c|c|}
\hline & (I) & (III) & (III) & (IV) \\
\hline \multirow[t]{2}{*}{ In(density) } & $0.060^{* * *}$ & $0.054^{\star \star \star}$ & $0.054^{\star \star \star}$ & $0.034^{* \star *}$ \\
\hline & $(0.013)$ & $(0.013)$ & $(0.013)$ & $(0.010)$ \\
\hline \multirow[t]{2}{*}{ In(area) } & $0.094^{* * *}$ & $0.092^{\star * *}$ & $0.094^{* * *}$ & $0.069^{* * *}$ \\
\hline & $(0.014)$ & $(0.015)$ & $(0.014)$ & $(0.013)$ \\
\hline \multirow[t]{2}{*}{ In(municipalit.) } & $-0.035^{\star \star \star}$ & $-0.037^{\star \star \star}$ & $-0.036^{\star * *}$ & $-0.029^{* \star *}$ \\
\hline & $(0.010)$ & $(0.009)$ & $(0.009)$ & $(0.008)$ \\
\hline $\ln ($ pop. in & 0.015 & 0.017 & $0.017^{*}$ & 0.012 \\
\hline catchment area) & $(0.011)$ & $(0.011)$ & $(0.010)$ & $(0.009)$ \\
\hline$\%$ university & & $0.431^{* * *}$ & $0.445^{\star * *}$ & $0.455^{\star \star *}$ \\
\hline graduates & & $(0.163)$ & $(0.159)$ & $(0.166)$ \\
\hline \multirow[t]{2}{*}{ Capital } & & -0.058 & -0.063 & -0.042 \\
\hline & & $(0.041)$ & $(0.041)$ & $(0.028)$ \\
\hline \multirow[t]{2}{*}{ Port } & & $0.029^{*}$ & $0.028^{*}$ & $0.032^{* * *}$ \\
\hline & & $(0.015)$ & $(0.015)$ & $(0.010)$ \\
\hline Herfindahl & & & 0.501 & 1.003 \\
\hline index & & & (1.237) & $(0.744)$ \\
\hline \multirow[t]{2}{*}{ Agriculture } & & & & -0.077 \\
\hline & & & & $(0.519)$ \\
\hline High-tech & & & & $1.053^{\star *}$ \\
\hline manufacturing & & & & $(0.465)$ \\
\hline Med. high-tech & & & & $0.991^{* * *}$ \\
\hline manufacturing & & & & $(0.348)$ \\
\hline Med. low-tech & & & & $2.168^{\star * *}$ \\
\hline manufacturing & & & & $(0.528)$ \\
\hline Low-tech & & & & $0.838^{\star *}$ \\
\hline manufacturing & & & & $(0.336)$ \\
\hline \multirow[t]{2}{*}{ Electricity } & & & & -0.577 \\
\hline & & & & (1.453) \\
\hline \multirow[t]{2}{*}{ Trade } & & & & 0.390 \\
\hline & & & & $(0.425)$ \\
\hline \multirow[t]{2}{*}{ Catering } & & & & $1.217^{*}$ \\
\hline & & & & $(0.698)$ \\
\hline Transport \& & & & & -0.209 \\
\hline communication & & & & $(0.620)$ \\
\hline \multirow[t]{2}{*}{ Finance } & & & & $1.517^{* * *}$ \\
\hline & & & & $(0.439)$ \\
\hline Real estate & & & & 0.461 \\
\hline$\&$ business & & & & $(0.499)$ \\
\hline Public & & & & $0.806^{\star}$ \\
\hline administration & & & & $(0.462)$ \\
\hline Education health & & & & -0.196 \\
\hline social work & & & & $(0.358)$ \\
\hline \multirow[t]{2}{*}{ Other services } & & & & $1.549^{\star * *}$ \\
\hline & & & & $(0.512)$ \\
\hline R-Squared & 0.841 & 0.855 & 0.855 & 0.920 \\
\hline Observations & 438 & 438 & 438 & 438 \\
\hline FUAs & 146 & 146 & 146 & 146 \\
\hline
\end{tabular}

Notes and data sources: see Table 1

Metropolitan areas are Functional Urban Areas with at least 500,000 inhabitants

Includes an interaction control of country and year fixed effects (Country x Year FE).

$* \star * / * * / *$ indicates a statistically significant coefficient at the $1 \% / 5 \% / 10 \%$ level. 
Table B3. Pooled regressions excluding one (2005-2007)

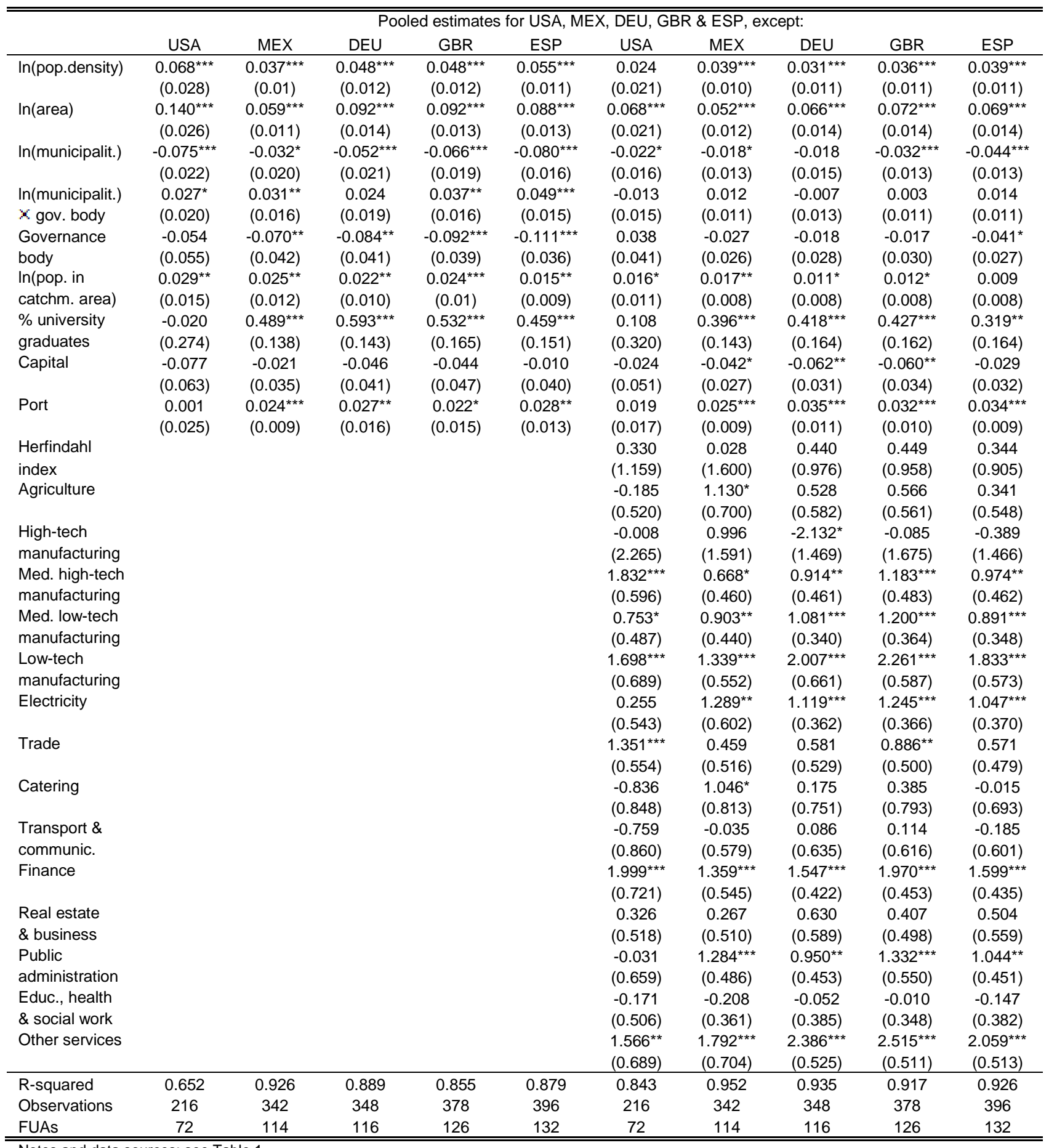

Estimates include only metropolitan areas, i.e. Functional Urban Areas with at least 500,000 inhabitants, since information on the presence of a governance body is not available for smaller FUAs.

Includes an interaction control of country and year fixed effects (Country $x$ Year FE).

$* \star * / * / *$ indicates a statistically significant coefficient at the $1 \% / 5 \% / 10 \%$ level. 


\section{REFERENCES}

Ahrend, R., Gamper, C. and A. Schumann, 2014, The OECD Metropolitan Governance Survey: A Quantitative Description of Governance Structures in Large Urban Agglomerations, OECD Regional Development Working Papers, forthcoming.

Ahrend, L. and A.C. Lembcke, 2014, Gross- and net- agglomeration benefits: Cross city disparities in Germany, OECD Regional Development Working Papers, forthcoming.

Baum-Snow, N. and R. Pavan Understanding the City Size Wage Gap, 2012, Review of Economic Studies, Vol. 79/1, pp. 88-127.

Berry, C. and E.L. Glaeser, 2005, The Divergence of Human Capital Levels across Cities. Regional Science, Vol. 84/3, pp. 407-444.

Blair, J., Staley, S. R. and Z. Zhang, 1996, The central city elasticity hypothesis, Journal of the American Planning Association, Vol. 62/3, pp. 345-354.

Cheshire, P. C. and I.R. Gordon, 1996, Territorial Competition and the Predictability of Collective (In)Action, International Journal of Urban and Regional Research, Vol. 20/3, pp. 383-399.

Cheshire, P.C. and S. Magrini, 2009, Urban Growth Drivers in a Europe of Sticky People and Implicit Boundaries, Journal of Economic Geography,Vol. 9, pp. 85-115.

Combes, P.-P., Duranton, G. and L. Gobillon, 2008, Spatial Wage Disparities: Sorting Matters!, Journal of Urban Economics, 63/2, pp. 723-742.

Combes P.-P., G. Duranton and L. Gobillon, 2011, The Identification of Agglomeration Economies, Journal of Economic Geography, Vol. 11, pp. 253-266.

Diaz, L., and I. Kaplanis, 2014, Agglomeration and productivity differentials in Spanish cities, OECD Regional Development Working Papers, forthcoming.

Djankov, S., C. McLiesh and R.M. Ramalho, 2006, Regulation and growth, Economics Letters, Vol. 92/3, pp. 395-401.

Duranton, G. and D. Puga, 2004, Microfoundations of urban agglomeration economies, in: Henderson, V. and J.F. Thisse (Eds.) Handbook of Regional and Urban Economics, Vol. 4, Elsevier, pp. 20632117.

Ellison, G. and E.L. Glaeser, 1997, Geographic Concentration in U.S. Manufacturing Industries: A Dartboard Approach, Journal of Political Economy, Vol. 105/5, pp. 889-927. 
Georgiadis, A. and I. Kaplanis, 2014, The Size and Sources of Productivity Differentials across Britain's Functional Urban Areas, OECD Regional Development Working Papers, forthcoming.

Gibbons, S., H.G. Overman and P. Pelkonen, 2010, Wage disparities in Britain: People or place? SERC/LSE discussion paper 0060.

Glaeser, E.L.. and D. Maré, 2001, Cities and Skills, Journal of Labor Economics, Vol. 19/2, pp. 316-342.

Glaeser, E.L. and M.G. Resseger, 2010, The complementarity between cities and skills, Journal of Regional Science, Vol. 50/1, pp. 221-244.

Greenstone, M., R. Hornbeck and E. Moretti, 2010, Identifying Agglomeration Spillovers: Evidence from Winners and Losers of Large Plant Openings, Journal of Political Economy, Vol. 118/3, pp. 536598.

Kaplanis, I., 2010, Wage effects from changes in local human capital in Britain, SERC/LSE Discussion Paper 0039.

Kaplanis, I. and C. Tello, 2014, Explaining productivity disparities in Mexican cities, 2000-2010, OECD Regional Development Working Papers, forthcoming.

Kim, S.-J., A. Schumann and R. Ahrend, 2014, What Governance for Metropolitan Areas?, OECD Regional Development Working Papers, forthcoming.

Melo, P. C., D. J. Graham and R. B. Noland, 2009, A meta-analysis of estimates of urban agglomeration economies, Regional Science and Urban Economics, Vol. 39/3, pp. 332-342.

Mincer, J.,1974, Schooling, Experience and Earning, National Bureau of Economic Research.

Monastiriotis, V., 2002, Human capital and wages: evidence for external effects from the UK regions, Applied Economics Letters, Vol. 9/13, pp. 843-846.

Moretti, E., 2004, Estimating the Social Return to Higher Education: Evidence from Longitudinal and Repeated Cross-Sectional Data, Journal of Econometrics, Vol. 121/1-2, pp. 175-212.

OECD, 2012a, Redefining "Urban": A new way to measure Metropolitan Areas, OECD Publishing, http://dx.doi.org/10.1787/9789264174108-en.

OECD, 2012b, OECD Territorial Reviews: The Chicago Tri-State Metropolitan Area, United States 2012, OECD Publishing, http://dx.doi.org10.1787/9789264170315-en.

OECD, 2013, OECD Regions at a Glance 2013, OECD Publishing, http://dx.doi.org10.1787/reg_glance2013-en.

Puga, D., 2010, The magnitude and causes of agglomeration economies, Journal of Regional Science, Vol. 50/1, pp. 203-219.

Rosenthal, S.S. and W.C. Strange, 2003, Geography, industrial organization and agglomeration, The Review of Economics and Statistics, Vol. 85/2, pp. 377-393. 
Rosenthal, S.S. and W.C. Strange, 2004, Evidence on the Nature and Sources of Agglomeration Economies, in: Henderson, V. and J.F. Thisse (Eds.) Handbook of Regional and Urban Economics, Vol. 4, Elsevier, pp. 2243-2291.

Ruggles, S., J.T. Alexander, K. Genadek, R. Goeken, M.B. Schroeder and M. Sobek, 2010, Integrated Public Use Microdata Series: Version 5.0 [Machine-readable database]. Minneapolis, MN: Minnesota Population Center [producer and distributor].

Schmucker, A. and S. Seth, 2009, BA-Beschäftigtenpanel 1998-2007. Codebuch. FDZ Datenreport $1 / 2009$.

UN, 2013, World Economic and Social Survey 2013: Sustainable Development Challenges.

World Bank, 2009, Systems of Cities: Harnessing Urbanisation for Growth and Poverty Alleviation. 